Article

\title{
Integrating Geophysical and Photographic Data to Visualize the Quarried Structures of the Roman Town of Bassianae
}

\author{
Roland Filzwieser ${ }^{1, *(\mathbb{D})}$, Vujadin Ivanišević ${ }^{2,3}$, Geert J. Verhoeven ${ }^{1,4}{ }^{\oplus}$, Christian Gugl ${ }^{5}$, Klaus Löcker ${ }^{1,6}$, \\ Ivan Bugarski ${ }^{2}$, Hannes Schiel ${ }^{1,6}$, Mario Wallner ${ }^{1,7}$, Immo Trinks $\left.{ }^{1,7}{ }^{(}\right)$, Tanja Trausmuth ${ }^{1}$, \\ Alois Hinterleitner ${ }^{1,6} \oplus^{\circ}$, Nemanja Marković ${ }^{2}$, Roald Docter ${ }^{4}$, Falko Daim ${ }^{8,9,10}$ and Wolfgang Neubauer ${ }^{1,7}$
}

Citation: Filzwieser, R.; Ivanišević, V.; Verhoeven, G.J.; Gugl, C.; Löcker K.; Bugarski, I.; Schiel, H.; Wallner, M.; Trinks, I.; Trausmuth, T.; et al. Integrating Geophysical and

Photographic Data to Visualize the Quarried Structures of the Roman Town of Bassianae. Remote Sens. 2021, 13, 2384. https://doi.org/ $10.3390 /$ rs13122384

Academic Editors: Vega Perez-Gracia, Oriol Caselles and Teresa Teixido

Received: 18 May 2021

Accepted: 16 June 2021

Published: 18 June 2021

Publisher's Note: MDPI stays neutral with regard to jurisdictional claims in published maps and institutional affiliations.

Copyright: (C) 2021 by the authors Licensee MDPI, Basel, Switzerland. This article is an open access article distributed under the terms and conditions of the Creative Commons Attribution (CC BY) license (https:/ / creativecommons.org/licenses/by/ $4.0 /)$
1 Ludwig Boltzmann Institute for Archaeological Prospection and Virtual Archaeology, Hohe Warte 38, 1190 Vienna, Austria; geert.verhoeven@archpro.lbg.ac.at (G.J.V.); klaus.loecker@archpro.lbg.ac.at (K.L.); hannes.schiel@archpro.lbg.ac.at (H.S.); mario.wallner@archpro.lbg.ac.at (M.W.); immo.trinks@univie.ac.at (I.T.); tanja.trausmuth@archpro.lbg.ac.at (T.T.); alois.hinterleitner@archpro.lbg.ac.at (A.H.); wolfgang.neubauer@archpro.lbg.ac.at (W.N.)

2 Institute of Archaeology, Knez Mihailova 35/IV, 11000 Belgrade, Serbia; vujadin.ivanisevic@gmail.com (V.I.); ivan.bugarski@gmail.com (I.B.); nemamarkovic@gmail.com (N.M.)

3 Serbian Academy of Sciences and Arts, Knez Mihailova 35, 11000 Belgrade, Serbia

4 Faculty of Arts and Philosophy, Department of Archaeology, Ghent University, Sint-Pietersnieuwstraat 35, 9000 Ghent, Belgium; roald.docter@ugent.be

5 Austrian Archaeological Institute, Austrian Academy of Sciences, Hollandstraße 11-13, 1020 Vienna, Austria christian.gugl@oeaw.ac.at

6 ZAMG-Zentralanstalt für Meteorologie und Geodynamik, Hohe Warte 38, 1190 Vienna, Austria

7 Vienna Institute for Archaeological Science, University of Vienna, Franz-Klein-Gasse 1, 1190 Vienna, Austria

8 Department of Prehistoric and Historical Archaeology, University of Vienna, Franz-Klein-Gasse 1, 1190 Vienna, Austria; falko.daim@univie.ac.at

9 Institute for Medieval Research (IMAFO), Austrian Academy of Sciences, Hollandstraße 11-13, 1020 Vienna, Austria

10 Landesamt für Denkmalpflege und Archäologie Sachsen-Anhalt-Landesmuseum für Vorgeschichte, Richard-Wagner-Straße 9, 06114 Halle an der Saale, Germany

* Correspondence: roland.filzwieser@archpro.lbg.ac.at

Abstract: Large parts of the urban layout of the abandoned Roman town of Bassianae (in present-day Serbia) are still discernible on the surface today due to the deliberate and targeted quarrying of the Roman foundations. In 2014, all of the town's intramural (and some extramural) areas were surveyed using aerial photography, ground-penetrating radar, and magnetometry to analyze the site's topography and to map remaining buried structures. The surveys showed a strong agreement between the digital surface model derived from the aerial photographs and the geophysical prospection data. However, many structures could only be detected by one method, underlining the benefits of a complementary archaeological prospection approach using multiple methods. This article presents the results of the extensive surveys and their comprehensive integrative interpretation, discussing Bassianae's ground plan and urban infrastructure. Starting with an overview of this Roman town's research history, we present the details of the triple prospection approach, followed by the processing, integrative analysis, and interpretation of the acquired data sets. Finally, this newly gained information is contrasted with a plan of Roman Bassianae compiled in 1935.

Keywords: Roman town; Bassianae; GPR; magnetometry; image-based modeling; UAS; archaeological prospection; Serbia

\section{Introduction}

\subsection{Bassianae's History}

Roman Bassianae or Bassiana (Serbian: Basijana/Басијана) is located in the Vojvodina province of present-day Serbia, in the eastern part of the Syrmia region near the village of Donji Petrovci, some $15 \mathrm{~km}$ east of the modern town of Ruma (Figure 1). The site is 
abandoned today but was once a flourishing Roman settlement, well-positioned along the road between the larger towns of Sirmium and Singidunum in the hinterland of the Danube limes. Thanks to this favorable geographic location, the settlement gradually developed until Emperor Hadrian (reign: AD 117-138) granted Bassianae its municipal status in the 2nd century AD [1]. Although it remains unclear to which extent the Marcomannic Wars (AD 167-180) affected Bassianae and its region, the plentiful epigraphic sources do shed some light on the town's later history. From the reign of Emperor Caracalla (reign: AD 211-217), Bassianae became referred to as Colonia and was home to numerous soldiers and veterans [1,2]. The town also remained largely unaffected by the late 3rd-century crisis in the Roman Empire [2,3].

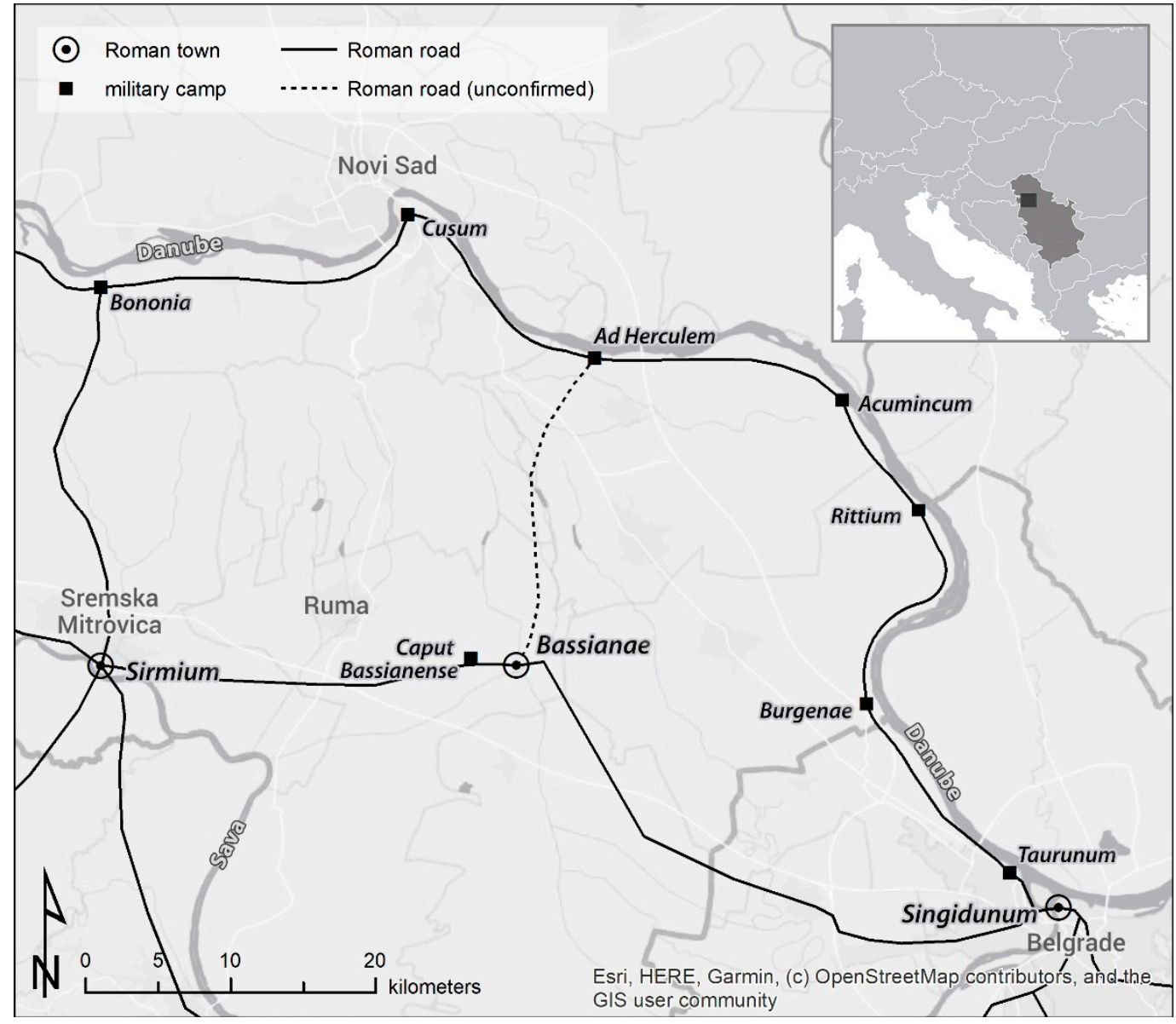

Figure 1. Location of Bassianae between Singidunum and Sirmium in present-day Serbia.

Due to its location, Bassianae kept its importance in the following century. However, Sarmatian raids in AD 374-375 and the Goths' movements after AD 378 must have affected the town and its territory. This crisis of the Later Roman Empire was characterized by the presence of new population groups, mostly of Germanic origin, and the impoverishment of the entire Roman province Pannonia Secunda. It is very illustrative that the Notitia Dignitatum (or. XI.46) [4] mentions the transfer of the late antique textile factory of Bassianae (Lat. gynaecium Bassianense) to the safety of Salona on the Adriatic coast. Invasions by, and fights against, the Ostrogoths and Huns during the 5th century AD would only add more burden to the region's population [2,3]. After the Roman Empire re-establishes control over the Bassianae area in AD 510, the town slowly vanishes from the sources. 


\subsection{Research History}

In the first half of the 20th century, the Bassianae town area was locally denoted the 'mine', a nickname for which an 1874 newspaper article provides the first explanatory clue, as it mentions how the local population has been quarrying this uninhabited site (Štrosmajer 1874, as cited in [5]). Eight years later, Bassianae's unique characteristics would disillusion Šime Ljubić from the National Museum in Zagreb. In 1882, Ljubić opened numerous excavation trenches-marked B-O on his plan (Figure 2a)-in areas where the apparent topographic features led him to assume the existence of town ramparts and towers (in Figure 2a indicated as "nasip", Croatian/Serbian for mound or bank). A total of five trenches targeted four assumed towers (B-E in Figure 2) and a location where he believed the ramparts to meet (Figure 2F). However, no substantial building traces were found, apart from a lead water pipe and a round stone column. Despite unearthing well-preserved walls at the eastern rampart (Figure 2O) and smaller wall fragments inside the fortification (I, L, M, N in Figure 2), the underwhelming amount of urban remains left Ljubić disappointed. He abandoned the site and concluded that Bassianae was merely a military camp with earthen ramparts [5].
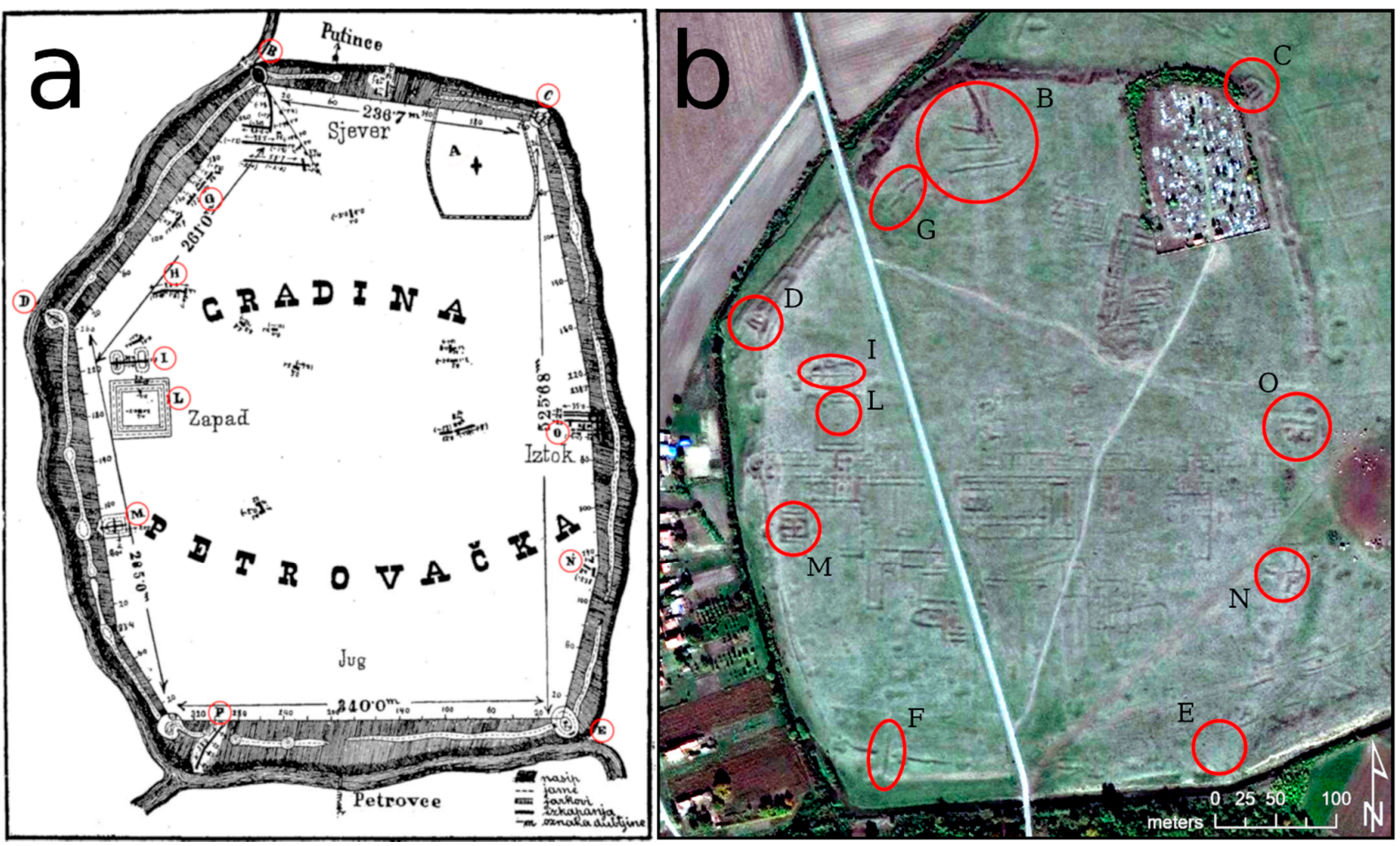

Figure 2. Plan from 1883, indicating Ljubić's excavation trenches (a) which are still visible in the present-day terrain (b). Plan: [5] p. 45. Image of b: Esri basemap by Esri, DigitalGlobe, GeoEye, i-cubed, USDA, USGS, AEX, Getmapping, Aerogrid, IGN, IGP, and the GIS User Community.

This interpretation was refuted by Miodrag Grbić, who led excavations at Bassianae in 1935 organized by the Historical Society of Novi Sad. Initially, Grbić unearthed the southern part of a three-nave basilica in the northern part of the town (Figure 3a1), along with three buildings in the central area at the intersection between the Cardo and the Decumanus streets (Figure 3a2). Whereas the severely damaged basilica only revealed a partial floor mosaic, more unaffected structures such as a hypocaust system, floral mosaic pavement, mortar floors, and a brick-built canal were attested in the central excavation area. In contrast, additional trenches dug in the southern and northwestern parts of the town later that 
year failed to reveal substantial wall remains [6]. These results convinced Grbic that the ramparts and walls had been quarried away for centuries by the local population searching for building material. Because this part of the Syrmian lowlands is poor in stone, Bassianae must have been considered a convenient source for 'mining' construction material, which explains their absence in most excavation trenches [7].

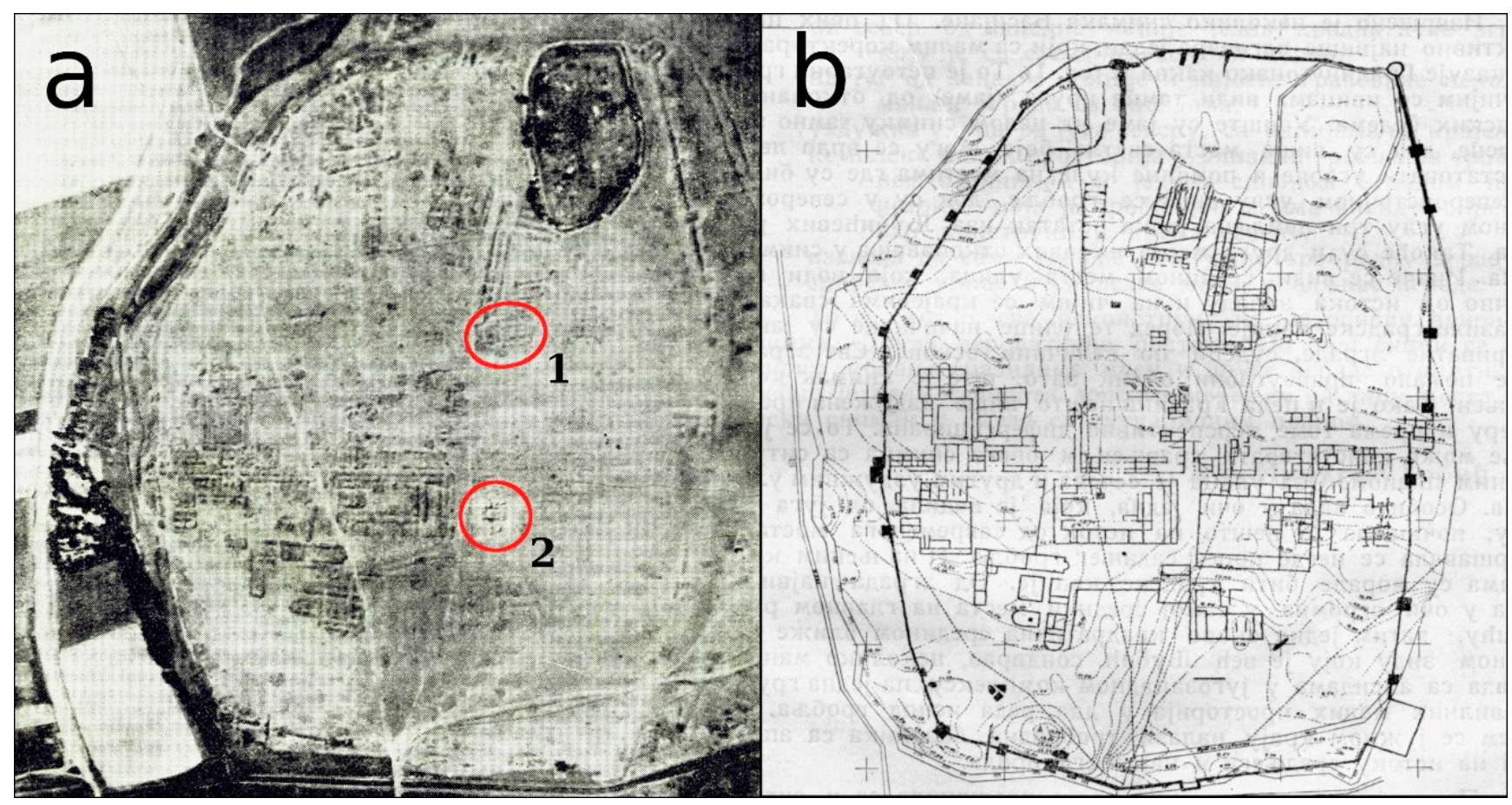

Figure 3. Aerial photograph of the site, taken in 1935 (a), marking the excavated areas of the basilica (1) and the three central buildings (2). Respective archaeological interpretative map from Richard Staudinger (b). Photo and plan are georeferenced versions of the illustrations in [8] (pp. 27 and 29).

Since Bassianae was never built over after its abandonment (or at least not with stone structures), and thanks to the characteristic topographic traces left by quarrying, the layout of the town's main elements is remarkably well observable from the air (see Figures 2b, 3a and 4). The earliest known airborne records of Bassianae date to 13 September 1935 (Figure 3a), when the Royal Yugoslav Air Force conducted an aerial survey above the site as part of the 1935 excavation campaign. Based on these airphotos and a geodetic plan of the Bassianae area (also made in 1935 to support the excavations [8]), the Belgrade-based German architect Richard Staudinger drew a detailed situation plan of the town (Figure 3b), in small parts confirmed by the 1935 excavations [8].

Although O.G.S. Crawford interpreted structures observed in aerial photographs from the 1920s onwards [9], and Dache Reeves implies that such interpretative maps were already more common at the time of Grbić's campaign [10], this example of airphoto interpretation can still be considered an innovative methodological approach for that time [11], especially in combination with the geodetic survey. Grbić eventually also published his research on Bassianae in the journal Antiquity [7], to which the editor, Crawford himself, although wishing for better aerial photographs, expressed his fascination with the site [12,13]. 


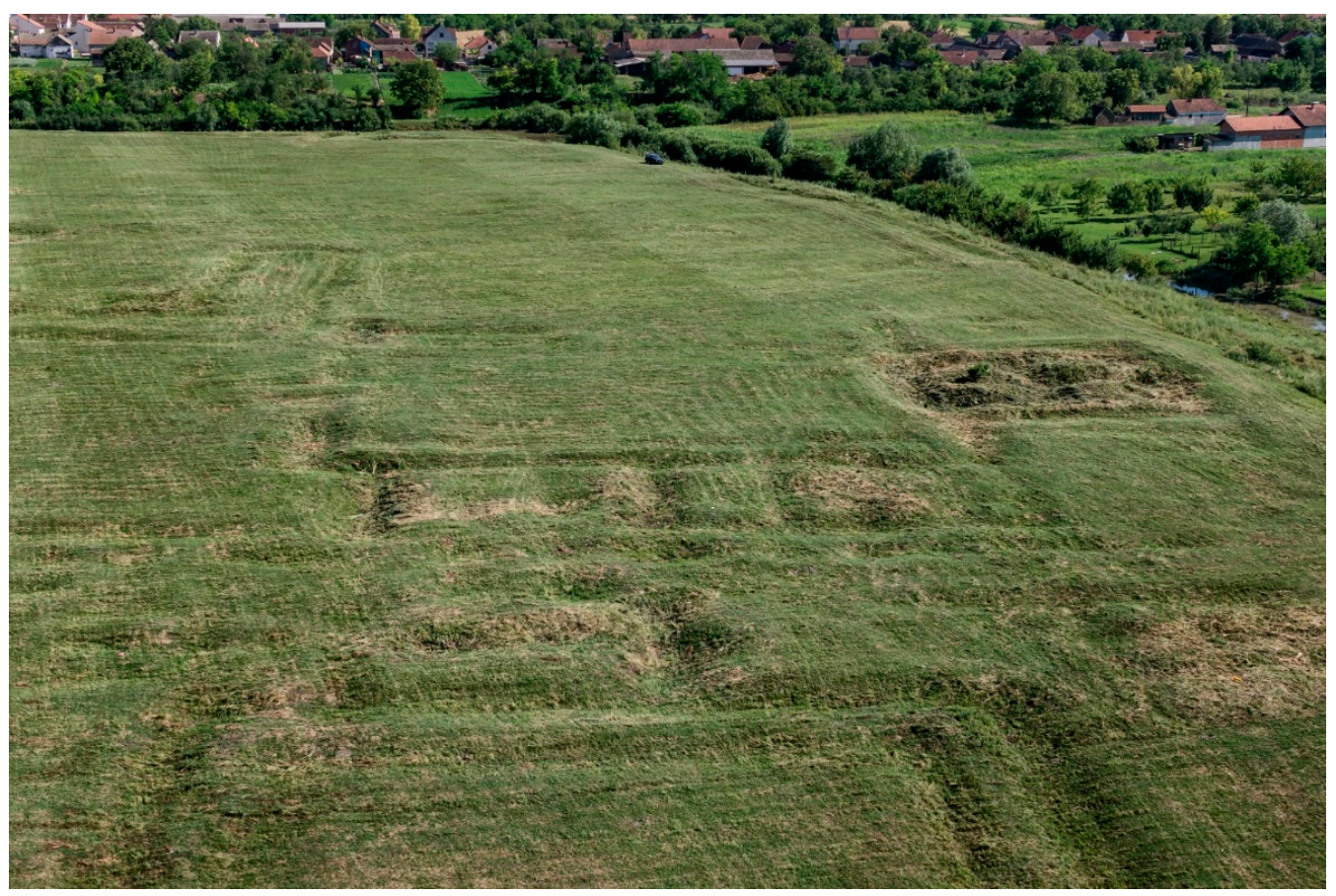

Figure 4. An oblique aerial photograph portraying the central and southern zone of the site's western part, acquired in 2014 with an unmanned quadcopter. The trenches following the former walls are still visible in the microtopography. The global contrast of the foreground has been slightly increased to enhance the visibility of the topographic undulations. Photo: Geert Verhoeven.

\subsection{New Goals and Research Questions}

To evaluate the accuracy of this early interpretative mapping and assess the added archaeological insight that different non-destructive prospection methods can bring to a site largely devoid of substantial material remains, the Vienna-based Ludwig Boltzmann Institute for Archaeological Prospection and Virtual Archaeology (LBI ArchPro) surveyed Bassianae in June 2014 in collaboration with the Institute of Archaeology in Belgrade, the Römisch-Germanisches Zentralmuseum Archaeological Research Institute (RGZM) in Mainz as well as the Austrian Academy of Sciences (OeAW-IKAnt) in Vienna. In line with the research competence of the LBI ArchPro, a three-layered prospection approach with terrestrial and airborne sensors was established: geophysical prospection with motorized Ground-Penetrating Radar (GPR) and Fluxgate magnetometer gradiometer systems, combined with aerial photography sorties executed by an unmanned aerial system (UAS). This airborne imagery was intended for processing inside an image-based three-dimensional (3D) modeling pipeline to generate an orthophoto and a Digital Surface Model (DSM) representing the site's topography. The following parts of the article present the data acquisition and processing stages (Part 2), detail the archaeological interpretation of the survey results (Part 3), and discuss the methodological and archaeological insights when compared to the research status from almost a century ago (Part 4).

\section{Materials and Methods}

In recent years, a growing number of Roman towns and military camps have been investigated with mechanically non-destructive methods to large extents [14-31]. Among those, Carnuntum $[15,18,21,25,32,33]$, Falerii Novi $[14,30,34]$, and Portus $[16,20,27,28]$ can be mentioned as three prominent examples. Although many of these Roman towns were researched through a combined terrestrial geophysics-airborne imaging approach, the Bassianae area is unique in its uniformness and emptiness. No Roman remains are directly visible on its uninhabited grassland surface situated on an alluvial fan. However, most of their removal can be decoded from the undulating surface, below which any archaeological 
remains are buried. Apart from the cemetery, the entire town area is construction-free and accessible to any form of archaeological prospection. In this case, motorized GPR surveys and magnetometer measurements along a UAS-based photographic survey took place between 25 June and 30 June 2014. Much of the high vegetation present in large parts of the site was removed to enable the surveys. Because most of this clearance took place simultaneously to the fieldwork, the aerial images' processing was seriously hampered (see Section 2.2.2).

\subsection{Geophysical Prospection \\ 2.1.1. Data Acquisition}

The high-resolution near-surface geophysical archaeological prospection surveys involved the deployment of motorized GPR array systems as well as motorized multichannel magnetic gradiometer carts. The GPR surveys were conducted with a six-channel Sensors and Software SPIDAR antenna array mounted in a custom-built trailer towed by an All-Terrain Vehicle (ATV). Six $500 \mathrm{MHz}$ PulseEkko PRO GPR antenna pairs were arranged next to each other with $25 \mathrm{~cm}$ crossline spacing, sampling GPR traces with a constant measurement frequency of $50 \mathrm{~Hz}$. This resulted in an inline trace spacing of approximately $5 \mathrm{~cm}$. The recording time window was set to $60 \mathrm{~ns}$, yielding a maximum penetration depth of circa three metres at an assumed subsurface GPR pulse velocity of $10 \mathrm{~cm} / \mathrm{ns}$. A standardized GPR pulse velocity of $10 \mathrm{~cm} / \mathrm{ns}$ has been assumed, corresponding to a dielectric constant or relative dielectric permittivity (RDP) of 10 . While dry sands would show RDPs from 3 to 5 with velocities of $13 \mathrm{~cm} / \mathrm{ns}$ to $17 \mathrm{~cm} / \mathrm{ns}$, increased silt or clay content reduces the velocity to values of $5 \mathrm{~cm} / \mathrm{ns}$ to $13 \mathrm{~cm} / \mathrm{ns}$ with corresponding RDPs ranging from 40 to 5 . A reduced pulse penetration depth was encountered, indicating increased contents of silt and clay in the soil of the alluvial fan. Data acquisition was realized with the application SPIVIEW from Sensors and Software. For efficient navigation, the in-house developed application LoggerVis was used.

The magnetometer system consisted of eight Förster FEREX CON650 gradiometer probes mounted with $25 \mathrm{~cm}$ crossline spacing on a six-metre long, bespoke, non-magnetic cart, providing sufficient distance to the metal parts and engine block of the towing ATV to prevent measurement induced disturbances in the prospection data as much as possible. Data acquisition was realized with a ten-channel Eastern Atlas EAL analogue/digital converter and the software LoggerVis, which functioned as data logger as well as navigation and guidance system. LoggerVis provided the possibility for real-time data visualisation and thus instantaneous data quality control in the field. A constant sampling frequency of $50 \mathrm{~Hz}$ resulted in an inline measurement spacing of $15 \mathrm{~cm}$ or less, depending on the driving speed.

To guarantee appropriate data positioning, three temporary fixed points were established by a local land surveyor in the WGS 84/UTM zone 34N (EPSG 32634) coordinate reference system. Every day, a JAVAD TRIUMPH-1 Global Navigation Satellite System (GNSS) base system was positioned above any of these fixed points, enabling Real-Time Kinematic (RTK) communication of positional data with TRIUMPH-1 rovers mounted on the GPR and magnetometer prospection systems. In field conditions without disturbances caused by trees or high-rise buildings, a planimetric positioning accuracy of $2 \mathrm{~cm}$ is assumed at a $5 \mathrm{~Hz}$ position data rate.

Due to technical issues with one of the ATVs, some GPR and some magnetometry measurements outside of the former town walls had to be conducted with a van as towing vehicle (Figures 5 and 6). This resulted in a somewhat reduced, yet sufficient data quality in case of the magnetic prospection data due to the increased magnetic influence of the car. The survey campaign's total coverage amounted to roughly 19.8 ha of GPR measurements and circa 27.4 ha of magnetometry. 


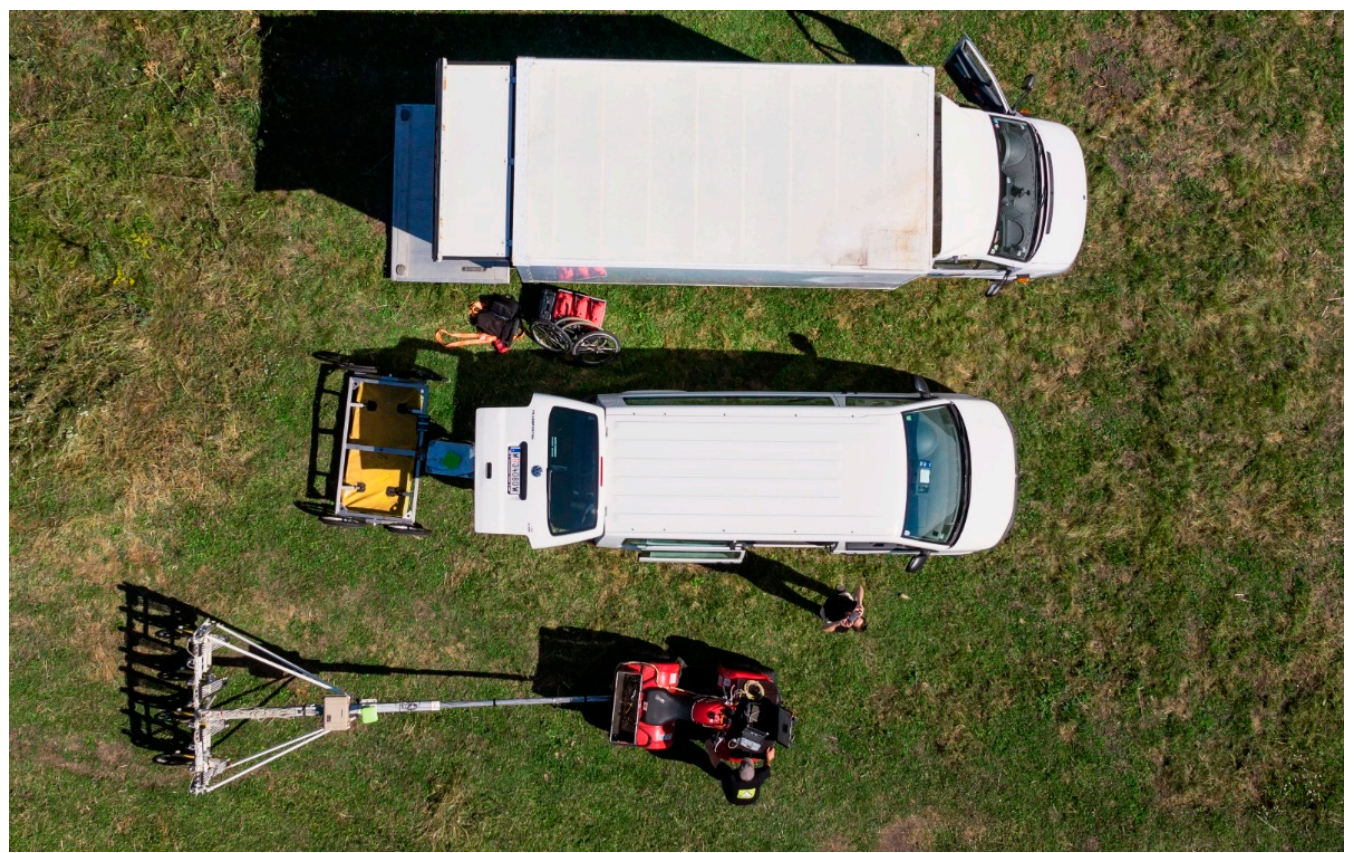

Figure 5. Aerial photograph of the 6-channel SPIDAR GPR system (center) and the magnetometer system (bottom) with their corresponding towing vehicles on site, photographed from the UAS. Photo: Geert Verhoeven.

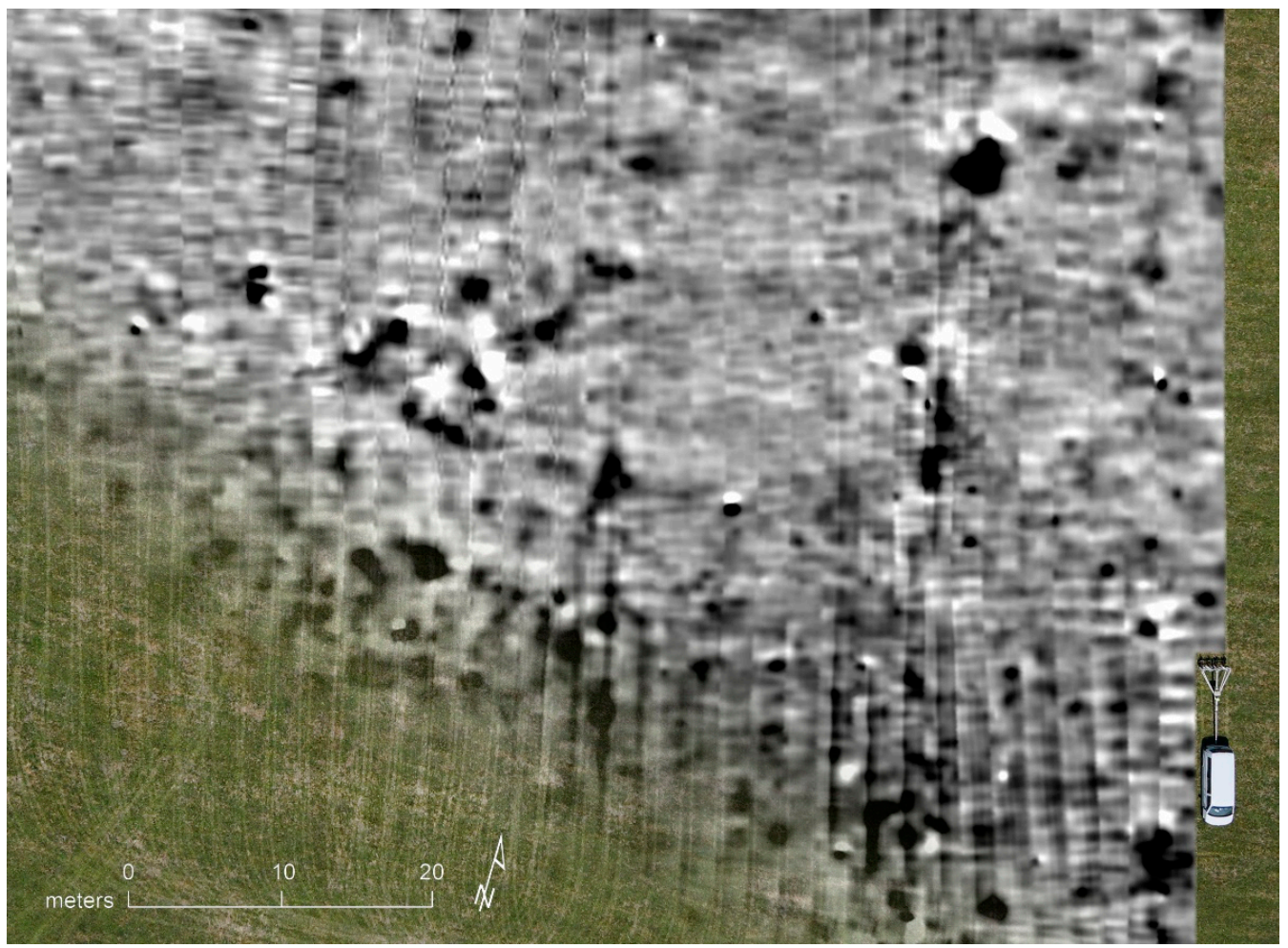

Figure 6. UAS-based aerial photograph showing the magnetometer prospection system towed by the van, superimposed with magnetic prospection data. The driven survey lines visible in the field as vehicle tracks match with the georeferenced magnetic data swaths. Due to the influence of the tow vehicle, some striping can be seen in the raw data, but the magnetic anomalies of archaeological interest are nevertheless clearly recognizable and enhanced after the application of respective filtering. Photo: Geert Verhoeven. 


\subsubsection{Data Processing}

The geophysical prospection data were processed with the specialist software solutions ApMag and ApRadar developed over the past ten years by the ZAMG and the LBI ArchPro. Since the Windows-based LoggerVis data acquisition software [35] is not real-time capable regarding the exact simultaneous sampling of the two ports on which the magnetic and position data streams arrive, a pulse-per-second marker is fed into the magnetic data stream from the RTK-GNSS rover. This exact time stamping enables to merge both data streams during data processing for exact data positioning.

In case of the magnetic prospection data, the individual sensor readings were first calibrated to a zero level and despiked then filtered to remove the directional effect of the tow vehicle and finally levelled by subtracting a running mean computed along data stretches of $40 \mathrm{~m}$ length [36]. The resulting data images were generated as georeferenced 254-values greyscale TIFFs ranging between white for the lowest and black for the highest data values. Images were produced with different dynamic ranges $(-2 \mathrm{nT},+3 \mathrm{nT} ;-4 \mathrm{nT}$, $+6 \mathrm{nT} ;-6 \mathrm{nT},+6 \mathrm{nT} ;-8 \mathrm{nT},+12 \mathrm{nT} ;-16 \mathrm{nT},+24 \mathrm{nT} ;-32 \mathrm{nT},+64 \mathrm{nT})$ to improve visualization and analysis of the magnetic anomalies. Shapefiles for sensor positions and coverage were generated automatically.

In case of the time-triggered GPR data, the following processing steps were applied: position assignment using a constant time delay to account for the inherent latency of the system, data alignment, adaptive time-zero correction, frequency band-pass filtering, average trace removal calculated along $20 \mathrm{~m}$ windows, weak stripe removal, inline data binning, grid mapping and interpolation, trace interpolation along one metre windows, and gain correction. A 2D migration with a velocity model decreasing from $12 \mathrm{~cm} / \mathrm{ns}$ at the surface to $10 \mathrm{~cm} / \mathrm{ns}$ at $40 \mathrm{~ns}$ was applied to focus the scattered energy as well as a Hilbert transformation for the GPR trace envelope calculation. As output, georeferenced GPR depth layer images of 5, 10, 20,30, 40, and $50 \mathrm{~cm}$ thickness were generated from the $2.5 \mathrm{~m}$ deep interpolated 3D data volume for subsequent analysis in a GIS. GPR depth-slice animations in the form of GIFs were prepared in addition to the possibility to animate the data images in a GIS using the custom developed ArcGIS toolbox ArchaeoAnalyst, which as well permits the interactive visualization of variable depth ranges (see [37]).

The GPR signal penetration depth was limited at Bassianae. This may be due to a high electrical conductivity of the soil possibly caused by a high clay content and probably amplified in many cases by a reduced ground coupling of the antenna array due to the strong topographic variations caused by the quarrying trenches. However, where possible, the antennae were towed directly on the surface to achieve optimal signal penetration.

\subsection{Airborne Imaging}

\subsubsection{Data Acquisition}

The UAS survey above Bassianae took place from Friday 27 to Sunday 29 of June 2014. Over three days, aerial imagery was acquired during nine UAS sorties (Table 1). All flights featured the md4-1000, a high-end electrical quad(ro)copter from microdrones $\mathrm{GmbH}$ (Figure 7). The multi-copter was equipped with a Sony NEX-5N, a 16.1-megapixel APS-C format mirrorless camera, with a Sigma $30 \mathrm{~mm} f / 2.8$ EX DN lens attached.

Because the aerial imagery was intended for image-based modeling (IBM) using photogrammetric and computer vision-based approaches [38], the acquired photographs had to facilitate the Structure from Motion (SfM) and Multi-View Stereo (MVS) algorithms that are at the core of such hybrid 3D modeling pipelines. Second, the airborne data should enable the creation of a raster DSM with a $5 \mathrm{~cm}$ cell size (and corresponding orthophoto). This means that image acquisition followed specific rules to ensure that both goals could be met. 


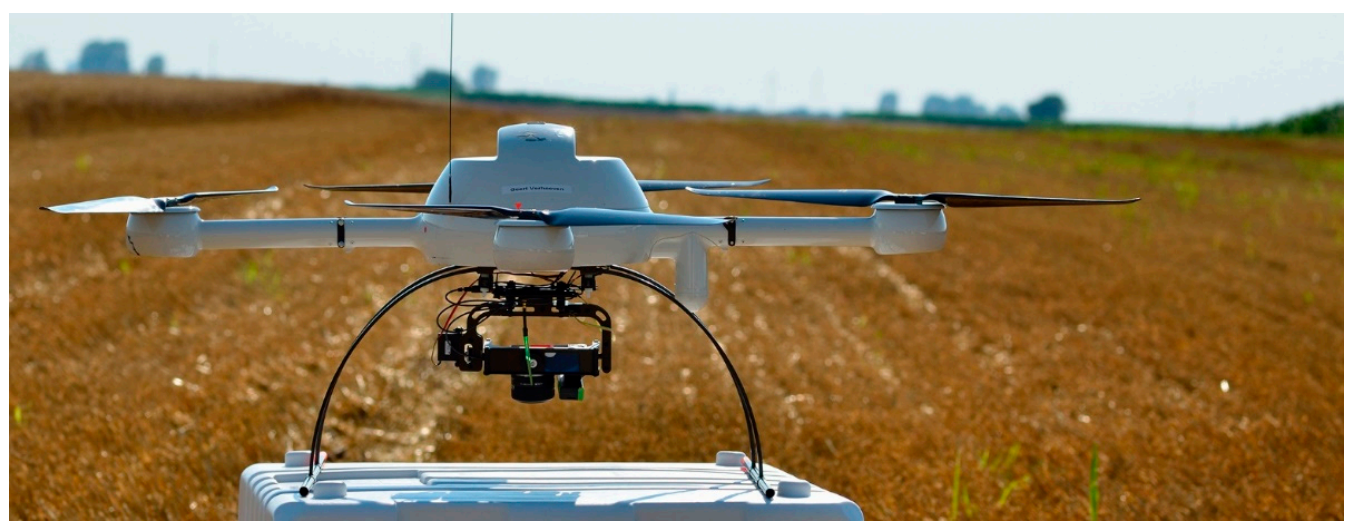

Figure 7. The md4-1000 quadcopter with a Sony NEX-5N mounted in a small carbon fibre camera mount on site. Photo: Geert Verhoeven.

Table 1. Overview of some important parameters of all nine UAS sorties.

\begin{tabular}{|c|c|c|c|c|c|}
\hline Parameter & Flight 1 & Flight 2 & Flight 3 & Flight 4 & $\cdots$ \\
\hline Date (day / month in 2014) & $27 / 06$ & $27 / 06$ & $27 / 06$ & $27 / 06$ & $\ldots$ \\
\hline Starting time & $14: 15$ & $14: 46$ & $15: 33$ & $16: 04$ & $\ldots$ \\
\hline Ending time & $14: 38$ & $15: 11$ & $15: 53$ & $16: 21$ & $\ldots$ \\
\hline Flight duration (minutes) & 23 & 25 & 20 & 17 & $\ldots$ \\
\hline Useful IBM images & 604 & 679 & 451 & 468 & $\ldots$ \\
\hline Average object distance (m) & 195 & 164 & 260 & 207 & $\ldots$ \\
\hline Average image GSD $(\mathrm{cm})$ & 3.1 & 2.6 & 4.1 & 3.3 & $\ldots$ \\
\hline \multirow[t]{10}{*}{ Footprint (width $(\mathrm{m}) \times$ height $(\mathrm{m})$ ) } & $152 \times 101$ & $128 \times 85$ & $203 \times 135$ & $161 \times 108$ & $\cdots$ \\
\hline & Flight 5 & Flight 6 & Flight 7 & Flight 8 & Flight 9 \\
\hline & $28 / 06$ & $28 / 06$ & $28 / 06$ & $29 / 06$ & $29 / 06$ \\
\hline & 09:24 & $15: 54$ & $16: 27$ & $11: 44$ & $12: 16$ \\
\hline & $09: 50$ & $16: 20$ & $16: 47$ & $12: 12$ & $12: 36$ \\
\hline & 26 & 26 & 20 & 28 & 20 \\
\hline & 685 & 671 & 228 & 877 & 432 \\
\hline & 112 & 171 & 37 & 127 & 144 \\
\hline & 1.8 & 2.7 & 0.6 & 2 & 2.3 \\
\hline & $87 \times 58$ & $133 \times 89$ & $29 \times 19$ & $99 \times 66$ & $112 \times 75$ \\
\hline
\end{tabular}

Before every flight, the Sigma lens was pre-focused on infinity and its focus ring fixed with cellophane tape. In that way, the camera's interior orientation was assumed to remain relatively stable throughout every flight. The camera's shutter was released every two seconds and images were acquired with an $f / 5.6$ aperture in aperture-priority mode. The ISO value and shutter speed were allowed to vary with the illumination conditions, but their respective values neither surpassed ISO 400 nor dropped below 1/1000 s. All photographs were saved in Sony's Alpha RAW image file format *ARW.

A partly broken UAS ground station necessitated manual operation of the md4-1000. Luckily, its planimetric position could still be monitored in real-time on-screen, and the entire survey area featured an unobstructed line of sight. The copter was steered in straight and long parallel lines over the site at a predefined altitude of about $150 \mathrm{~m}$. Given the $30 \mathrm{~mm}$ lens and $4.8 \mu \mathrm{m}$-detector pitch of the Sony NEX-5N, this altitude yields images with a $2.4 \mathrm{~cm}$ Ground-Sampling Distance (GSD), considered suitable for extracting 3D topographic details up to $5 \mathrm{~cm}$ (and enabling a DSM raster cell size of $2.4 \mathrm{~cm}$, which is twice as small as needed). The copter continuously moved at about $5 \mathrm{~m} / \mathrm{s}$ to maximise the area covered by each flight and avoid platform vibrations originating from slowing down and hovering. The slowest shutter speed of $1 / 1000 \mathrm{~s}$ was still fast enough to avoid pixel smear exceeding half a GSD (at $5 \mathrm{~m} / \mathrm{s}$, pixel smear is only $1 \mu \mathrm{m}$ in image space or $5 \mathrm{~mm}$ in object space). A handful of long cross lines were flown at a lower altitude in addition to the parallel flights. Both sets of nadir images were complemented by over one hundred oblique images, obtained in three panorama-style acquisitions at different spots of the survey area. 
These deliberate changes in image scale (intra- and inter-image) and sensor rotation create a more robust camera network geometry and improve the camera self-calibration accuracy during the SfM stage [39].

Due to the faulty ground station, the operational altitude changed from flight to flight (see Table 1). Such varying flight altitudes yield photographs with different GSDs, which is problematic for an image-based modeling pipeline that aims to extract a minimum amount of pre-defined spatial detail. However, the more severe implication for extracting complete and accurate 3D geometry was the violation of the foreseen $65 \%$ lateral image overlap. Three flights were unintentionally executed at altitudes much lower than the anticipated $150 \mathrm{~m}$, which led to smaller image footprints and a resulting drop in image overlap to only $55 \%$ in a few instances. For a scene that primarily consists of monotonic grass patches (some of which dynamically changed-see later), this is a problematic situation. Fortunately, the other flights' higher-than-anticipated flying altitudes largely mitigated this lack of overlap at the expense of a lower and variable GSD.

Finally, white circular cardboard plates with a diameter of $25 \mathrm{~cm}$ were distributed over the survey area. Their center coordinates were measured with the JAVAD TRIUMPH-1 rover, resulting in a collection of $963 \mathrm{D}$ point coordinates that could be used as ground control points (GCPs) to constrain the SfM bundle adjustment. This GNSS receiver had to be held close to the ground by the surveyor because only a short mounting pole was available (due to personal oversight), which decreased the hope of obtaining highly accurate coordinates. Because the UAS flights took place during the geophysical surveys, it was impossible to position and measure all targets in one run: the GPR instruments would ruin the targets, while the iron nails would interfere with the magnetic sensors. Positioning and topographically surveying these targets took, therefore, place during three consecutive days. Some targets were surveyed twice in this process, which meant that one could compare both coordinate triples. The resulting mean coordinate difference of $2.7 \mathrm{~cm}$ in planimetry (with a maximum of $6.5 \mathrm{~cm}$ ) and $6.9 \mathrm{~cm}$ in elevation (with a $13.3 \mathrm{~cm}$ maximum) indicate that the accuracy of some measurements had indeed suffered from the effects mentioned above.

\subsubsection{Data Processing}

The sub-optimal GNSS survey and image acquisition geometry brought about a very time-consuming processing phase. On top of that, the scene itself also changed during image acquisition. Upon arrival, long vegetation was still partly covering the Bassianae survey area. Because geophysical prospection occurs ideally on fields void of long grass and bushes, the latter were cut (and sometimes also removed) during the survey days, thereby creating a few drastic changes across certain parts of the site (see Figure 8a,b). Towing the geophysical instruments also patterned the grass (Figure 8c,d). However, these scenery changes posed only a minor issue during the data processing. In the end, the whole IBM processing pipeline consisted of numerous tests and many workflow iterations. Since this paper cannot solely focus on processing these data, the following paragraphs summarise the DSM's creation, while [40] provides more details.

After the conversion of the *.ARW files into 8-bit JPEGs using Adobe Lightroom 5, blurry and documentation-style images were deleted to yield a final set of circa 5100 photographs. All image pixels belonging to persons, cows, cars, and geophysical instrumentation were masked in Agisoft Metashape Professional version 1.7.1. Image areas depicting vegetation changes were left unmasked as masking typically prevented the estimation of these images' exterior orientation. Photos were grouped to compute flight-specific interior camera orientations. After an outlier detection based on a leave-one-out cross-validation (LOOCV) [41], the coordinates of 93 out of 96 reference points were withheld and used as GCP. The center of these 93 targets was indicated in every photograph that depicted them, resulting in approximately 3900 Metashape markers. Upon running the SfM algorithm, Metashape was instructed to use maximally 40,000 interest and 4000 tie points per image; the camera self-calibration solved for three radial $\left(k_{1}, k_{2}, k_{3}\right)$ and two decentering lens 
distortion parameters $\left(p_{1}, p_{2}\right)$. The coordinates of the 93 GCPs were determined to be $2 \mathrm{~cm}$ accurate, whereas indicating these points in the images was quantified with a 3-pixel accuracy. Many tests revealed that these two values provided the best weighting of the control data within the SfM's bundle adjustment. They resulted in the lowest positional inaccuracy (see later) of a DSM with minimal surface artefacts (see also later).
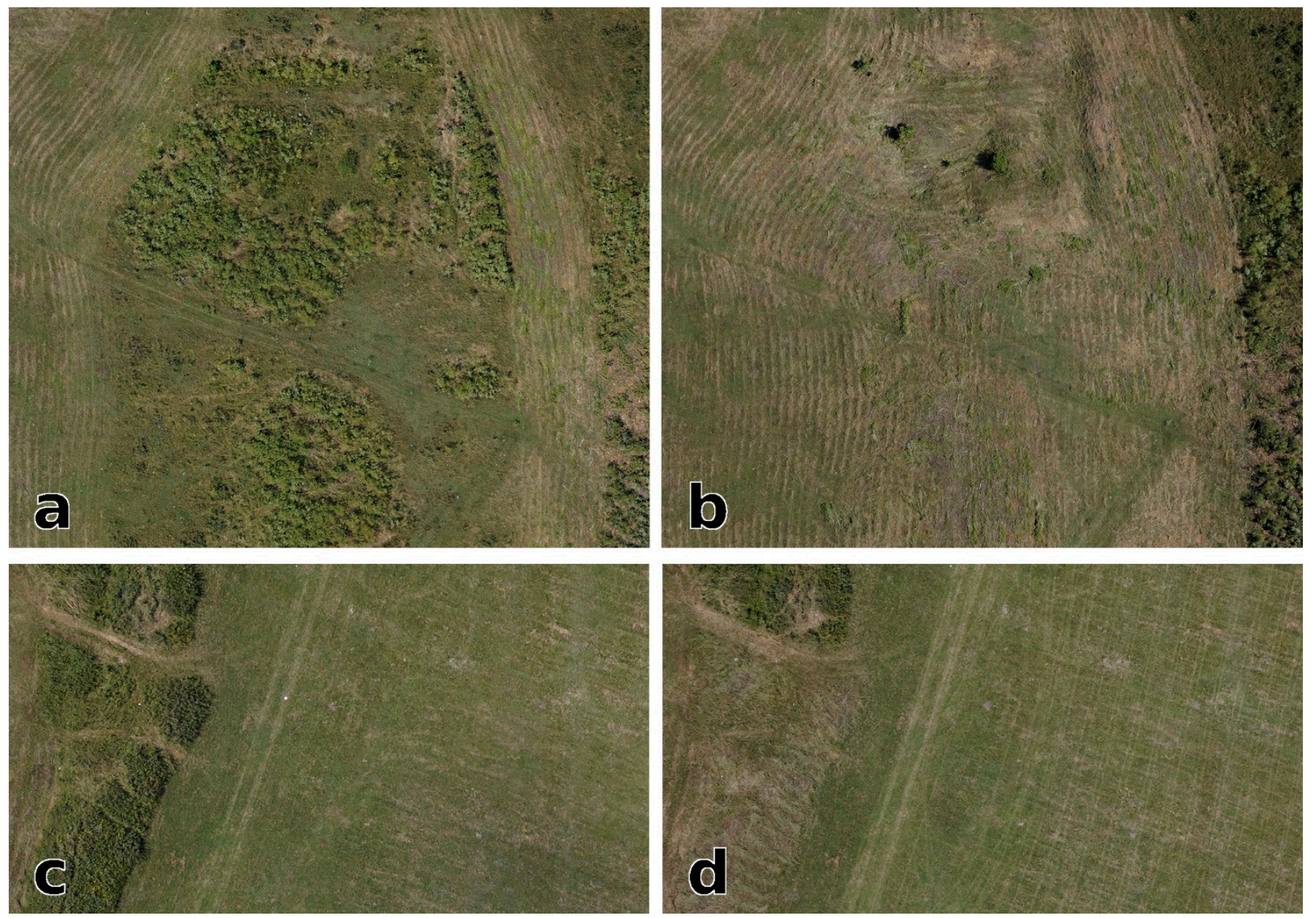

Figure 8. During Bassianae's UAS survey, the scene was anything but spatially invariant. Images (a,b) cover the same scene, but they look quite different, which illustrates some of the severe surface changes that occurred due to vegetation clearing. These changes are also observable on the left sides of insets $(\mathbf{c}, \mathbf{d})$. The grass patterns resulting from the geophysical survey were less obtrusive (compare the right sides of $(\mathbf{c}, \mathbf{d})$ ).

With the interior and exterior camera orientations from the SfM step as input, the MVS step can yield a dense and continuous 3D surface encoding. To that end, Metashape offers two different approaches, both based on the computation of a depth map for each input view. However, rather than a 3D surface, the aim was to create a regularly gridded 2.5D DSM of the Bassianae area. The 2.5D elevation rasters are, together with triangulated/triangular irregular networks or TINs, the prevalent surface representation schemes used within GIS environments because most GIS software struggles till this very day with large, meshed 3D elevation models [42]. The 2.5D height fields and TINs effectively discard half a geometrical dimension when compared to 3D surface encodings. The associated information loss notwithstanding, this dimensional reduction makes 2.5D rasters suited for the fast execution of specific computational methods (such as relief visualizations). Besides, such elevation rasters can often satisfactorily approximate any surface that lacks quasi-vertical walls, overhangs, and under-cuttings. 
Although Metashape could derive this 2.5D DSM from a dense 3D point cloud or 3D mesh, Figure 9 reveals that a depth maps-based approach-available since version 1.6.0 (build 9617) [43]—offered much cleaner surfaces with fewer artefacts for the Bassianae dataset. In agreement with the initial aim, the cell size for this $2.5 \mathrm{D}$ DSM was $5 \mathrm{~cm}$, extracted using aggressive depth map filtering to maximally remove surface noise resulting from changing vegetation. Even though the image set comprised varying GSDs, the final DSM looks very convincing, apart from four zones that feature medium surface artifacting (see Figure 9 for the region with the most noticeable artefacts). These unsolvable artefacts are likely due to erroneous exterior orientation values of the cameras in areas with low image overlap. Luckily, these zones are not coincident with important topographic features and did, as such, not hamper the interpretive mapping of the DSM. Finally, this DSM was also used to compute the site's orthophotograph with a $5 \mathrm{~cm}$ GSD (see Figure 10d).
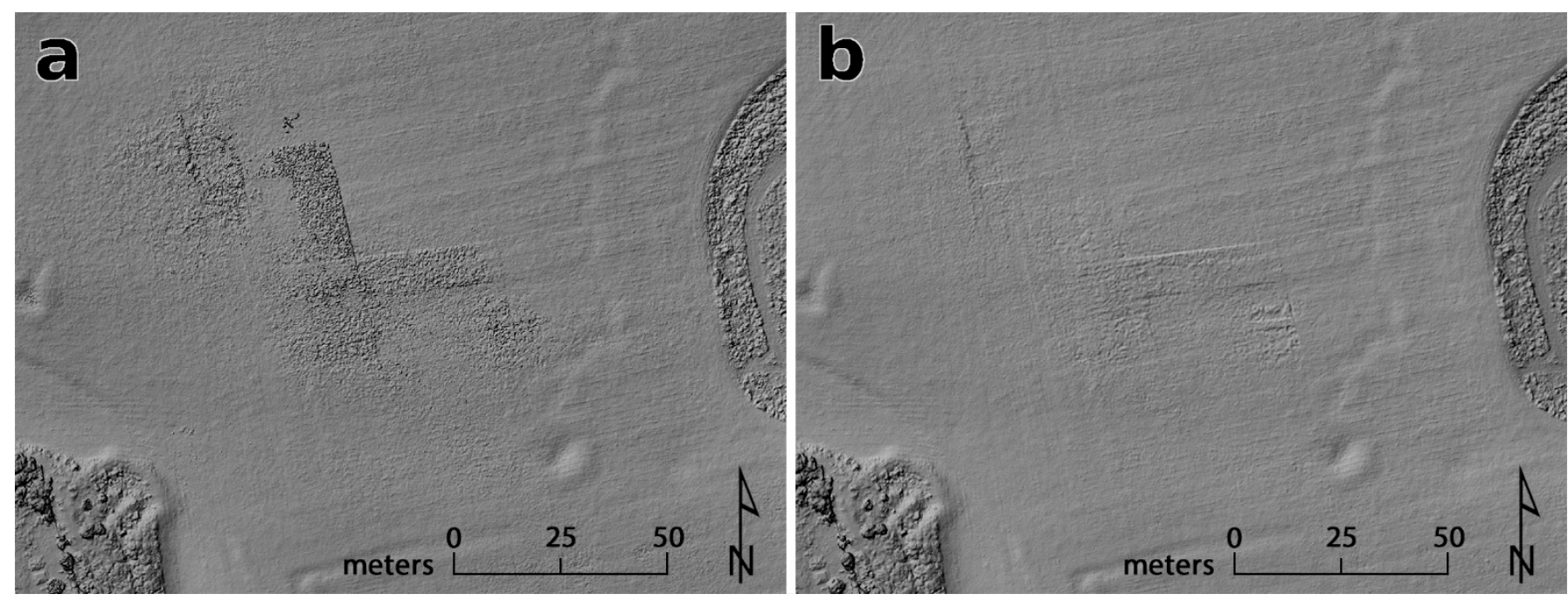

Figure 9. The 2.5D DSM computed from a meshed dense 3D point cloud (a) and directly from the merged depth maps (b). Notice the reduction of surface artefacts in (b). Both DSMs are rendered as hillshade with $55^{\circ}$ solar azimuth and a $35^{\circ}$ solar elevation.

With all 93 reference points used as GCP, the DSM and orthophoto's positional accuracy had to be determined via a LOOCV procedure [44,45]. The mean of all $93 \mathrm{LOOCV}$ residuals yielded: $X=2.3 \mathrm{~cm}, Y=2.8 \mathrm{~cm}, Z=4.2 \mathrm{~cm}, X Y Z=6.2 \mathrm{~cm}$. However, it is important to note that this and similar positional accuracy metrics (such as a common hold-out validation) often fail to account for DSM artefacts such as those depicted in Figure 9. 


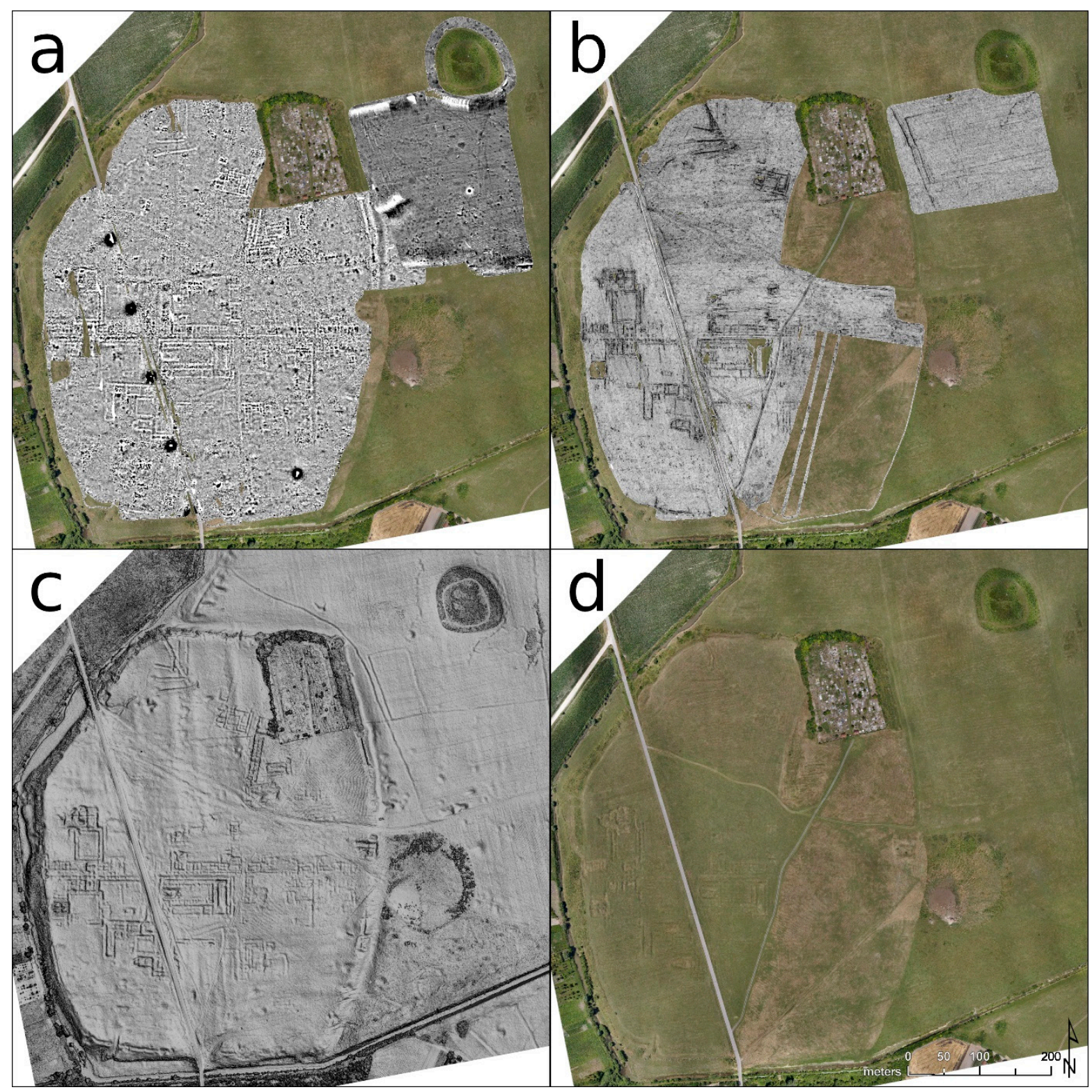

Figure 10. Archaeological prospection data of the central area at Bassianae. (a) Magnetic data image with greyscale values of $-6 \mathrm{nT}$ (white) and +6 nT (black); (b) GPR depth-slice from approximately 1.0 to $1.2 \mathrm{~m}$ depth; (c) multidirectional hillshade of the DSM with $3 \times$ Z exaggeration; (d) orthophotomosaic of all UAS images. In contrast to the 1935 aerial photo depicted in Figure 3a, the orthophotograph shown in (d) does not reveal all surface undulations. These are only visible from the air through the proxy of shadow marks. However, the 2014 aerial sorties were not solely flown during low-slanting sunlight conditions (as those of Figure 4) because the DSM offers many ways to visualize these topographic differences.

\section{Results}

The datasets gathered with the three survey methods are comprehensive and many features mapped show a high degree of correlation. However, due to the different characteristics of the respective datasets, as well as the distinct properties of the survey systems, there are also differences visible in the data (Figure 10).

These variations are partly caused by the difficulties posed by the rugged terrain, which prevented ideal ground-coupling of the GPR antenna array and rendered the use of the motorized magnetometer system with the large, towed sensor cart, as well as the GPR array, very difficult across the deep trenches. More importantly, the differences in the datasets concern the fringes of the measured area along the former town walls. This 
area could not be investigated by geophysical prospection due to the steep slopes and the high vegetation. Luckily, the image-based DSM made it possible to investigate this area, depicting major parts of the town wall and its towers (Figure 11c and 13). Thus, the combined interpretation (Figure 11d and 17) provides considerably more information than that of any individual dataset, clearly demonstrating the advantages of an integrative, multi-methodological archaeological prospection approach [46-48].

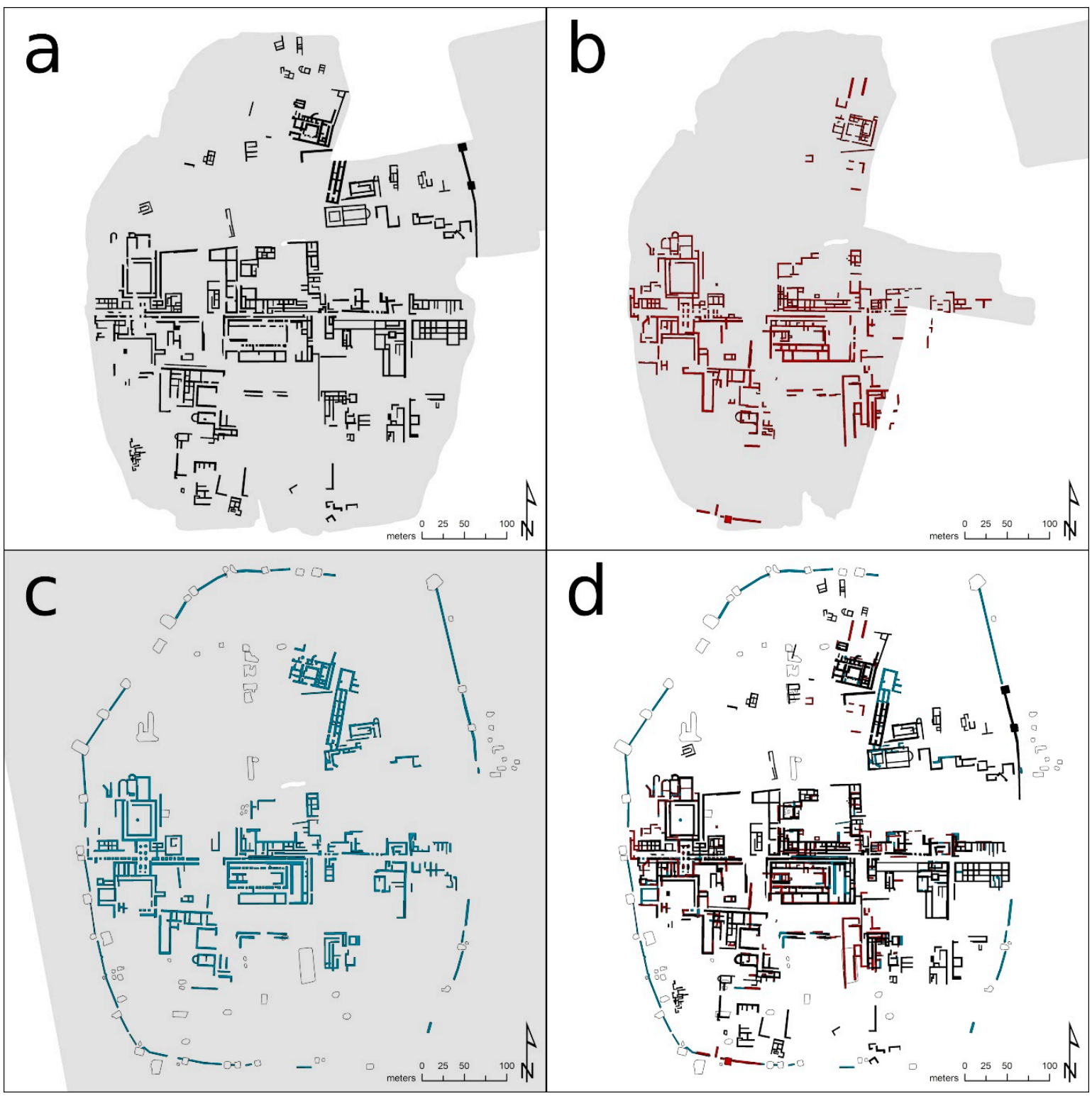

Figure 11. Comparison of the archaeological interpretations of the (a) magnetic, (b) GPR, and (c) topographic data sets, showing the respective coverage areas shaded in grey. (d) Combined information on wall structures derived from the interpretation of all three data sets.

To enable a quantitative comparison of the detected structures in the area covered by all three methods, the cumulative length of all subjectively interpreted walls in the respective datasets was calculated. In the radar data, walls with a total length of $3537 \mathrm{~m}$ were detected, in the DSM $4998 \mathrm{~m}$, and in the magnetic data $6010 \mathrm{~m}$. These numbers would suggest that magnetometry yielded overall the best results. However, some additional aspects should be considered. First, each method revealed (parts of) structures that were not picked up in the other datasets (Figure 11). Second, the individual methods often reveal 
different aspects of the same features (e.g., excavation trenches versus buried wall remains). In this way, each dataset contributes to the overall picture of archaeological structures that once were present or still are buried, permitting an integrative archaeological interpretation. The next paragraphs will detail the interpretation of the three datasets.

\subsection{Digital Surface Model}

A major advantage of the 2.5D raster DSM, apart from providing access to steep or heavily overgrown zones, is that it enables the fast computation of visualizations that can clearly reveal topographic features. The origin of these features seems rather unambiguous. They primarily correspond to trenches dug to deliberately quarry Roman walls. However, these DSM-derived features do not disclose any temporal information, nor their creator. In addition, one cannot assume that every trench corresponds to a former Roman structure. Although it is very probable that most quarrying took place when the structures were (partially) preserved above ground, numerous search trenches and ditches connecting neighbouring walls are to be expected. Despite this uncertainty, the DSM and its numerous visualizations constitute an important basis for the archaeological interpretative mapping. However, cross-checking with the geophysical results remained crucial. Interpreting the topographic undulations was carried out on local dominance [49], positive openness [50,51] and simple local relief model [52] visualizations computed with the Relief Visualization Toolbox [53,54]. To enhance their interpretative power, these three visualizations were also fused inside Adobe Photoshop (version 22.1.1) with a multidirectional hillshade computed within QGIS 3.14 (e.g., Figure 12a). Avenza's Geographic Imager 6.3 plugin enabled the handling of georeferencing information inside Photoshop.

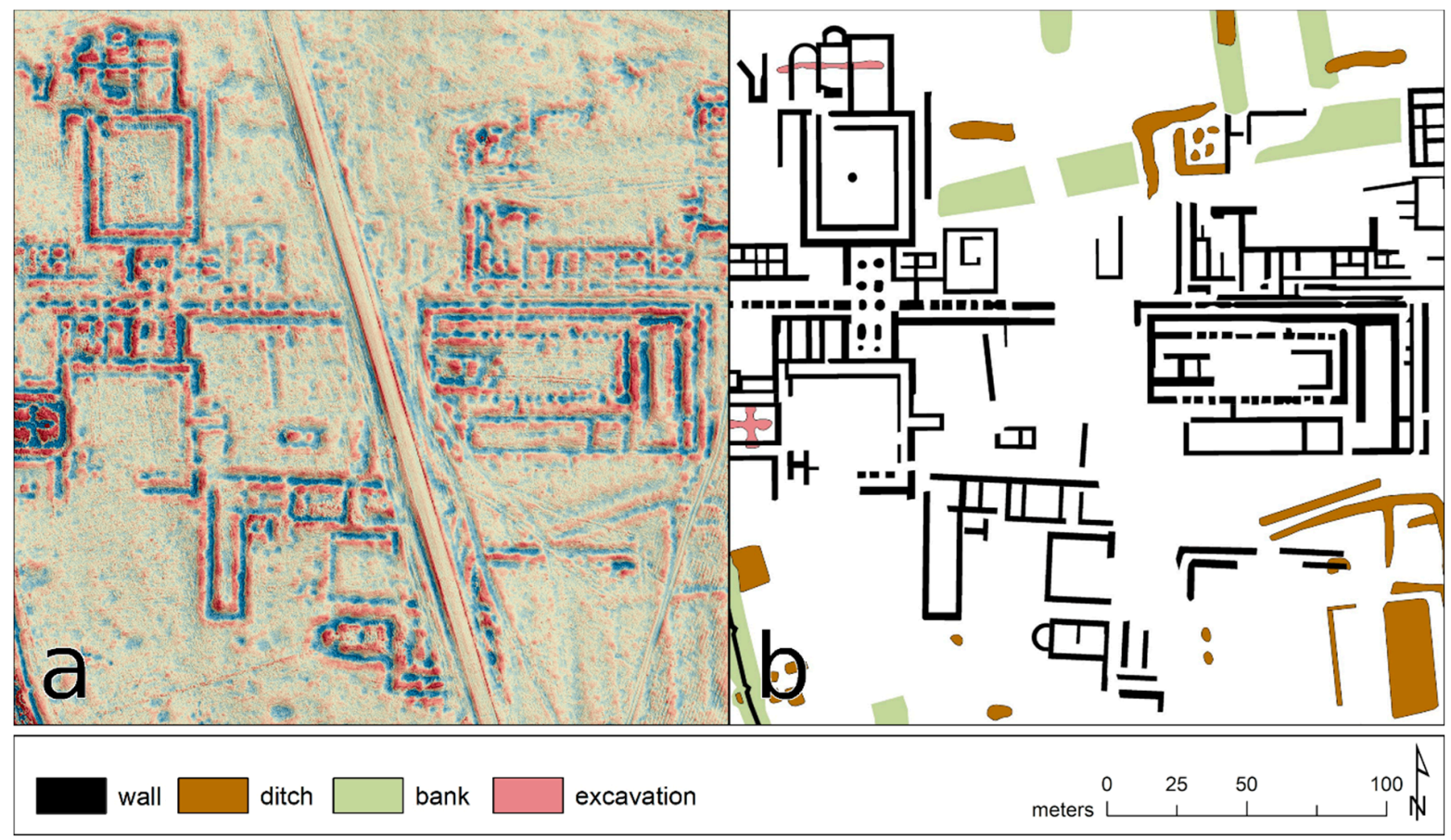

Figure 12. (a) Detail of a fused DSM visualization: a simple local relief model (circular kernel with 40 cells radius, $(-0.15 \mathrm{~m}$, $0.15 \mathrm{~m}$ ) clip, blue-yellow-red colour map) merged with a multidirectional hillshade $\left(35^{\circ}\right.$ solar elevation, vertical exaggeration factor of 3) using two iterations of the "hard light" blending mode with varying opacity levels. The contrast of both source layers was slightly altered before the initial blending. (b) Corresponding archaeological interpretation.

Regarding an overall understanding of the town, with its fortifications, road network and separate insulae, the DSM-orthophotograph blend should probably be considered the most informative source (Figure 13). This fused rendering offers a clear representation of all major building complexes and structures, while simultaneously allowing for the exact 
tracing of the town walls and its towers in areas where no geophysics could be applied. Furthermore, in the north of the town in an area with very few other structures, there are several parallel and rather shallow banks to be recognized in the terrain (Figure 12 light green, Figure 13). These are superimposed by other topographic features, which gives some stratigraphical clues about their age, and are oriented to the insulae emerging in the town center. Also, they are respected by most other archaeological structures found in the geophysical data. Thus, in most of the cases, they were interpreted as the remains of the former streets' embankment, in an area with rather small dwellings, of which there is little left.

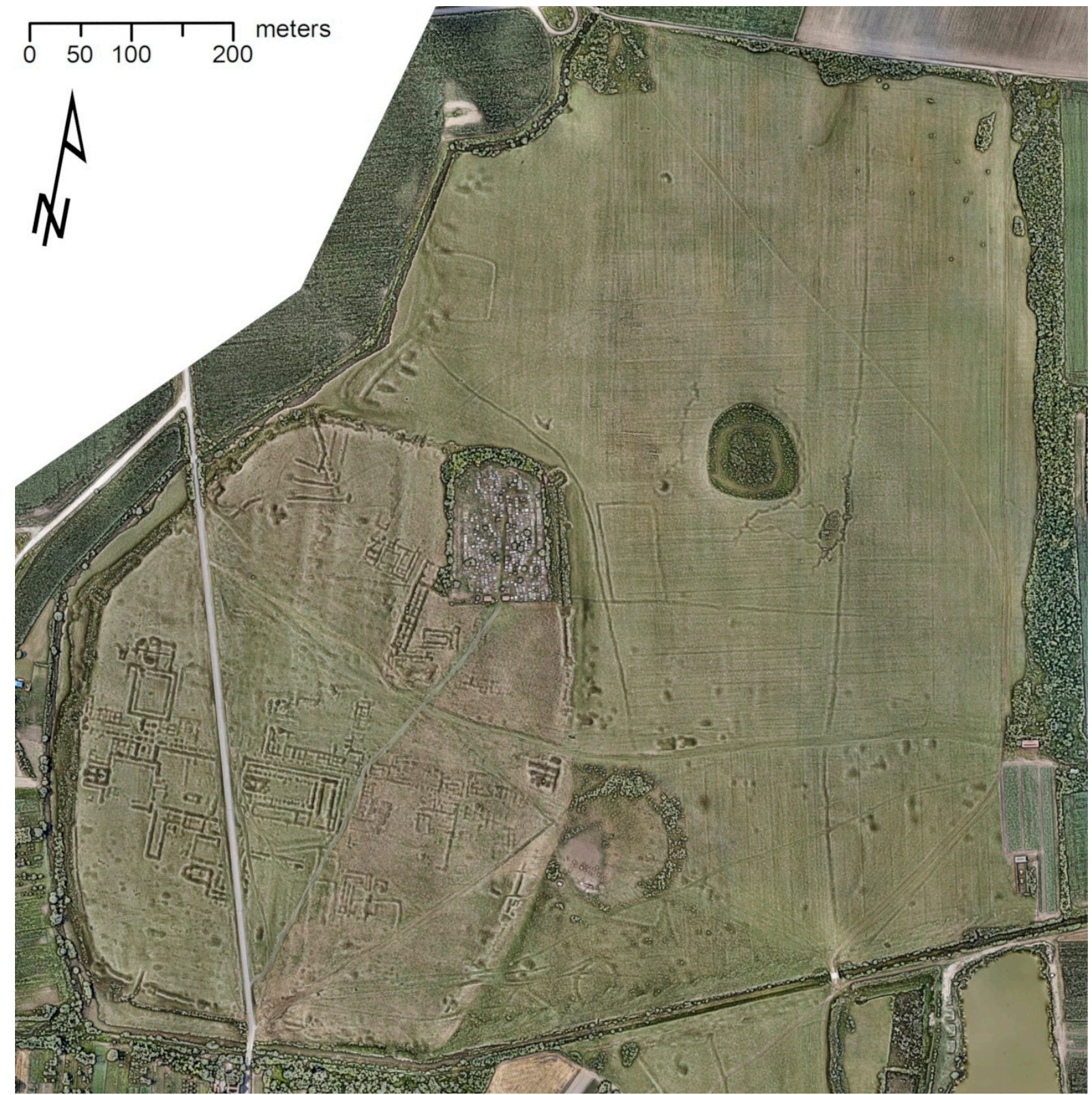

Figure 13. Visualization of present-day Bassianae using a "hard light" image fusion of the UAS imagery-based orthophoto with a relief rendering, the latter being the result of a "hard light" image fusion between a multidirectional hillshade (35 solar elevation, vertical exaggeration factor of 3$)$ and local dominance visualization $((\min , \max )$ kernel radii $=(20,40)$ raster cells) of the DSM. Opacity levels and global contrast levels were tuned for each intermediary fused result to achieve optimum clarity of the topographic features. 


\subsection{Ground-Penetrating Radar}

The archaeological prospection using GPR measurements faced several challenges at Bassianae, which also affected the archaeological interpretation of the data. Because the undulating terrain featured some steep slopes within deep and narrow trenches, several crucial areas could not be accessed with the GPR antenna array (Figure 14a), whereas magnetic measurements could still be conducted. In areas where the width of topographic depressions was smaller than the length of the GPR array towed perpendicular to it, it was not possible to maintain ground coupling for the antenna array, leading to reduced GPR pulse penetration depth and thus decreased data quality. Nevertheless, in many cases, the GPR measurements made it possible to determine the exact dimensions, orientation, and internal structure of surveyed buildings (Figure 14). They were also the most significant data for a comprehensive interpretation of structures observed in the terrain model and the magnetic data. This concerned mainly the depth of the respective structures, which cannot be estimated at all from the other data sets, as well as their actual dimensions, which are better approximated by the radar data [37]. Archaeological structures primarily appeared in the GPR data as strongly reflective linear features, which were typically interpreted as the buried remains of stone walls. In between, numerous more extensive and less reflective structures also indicate possible stone floors and road foundations.

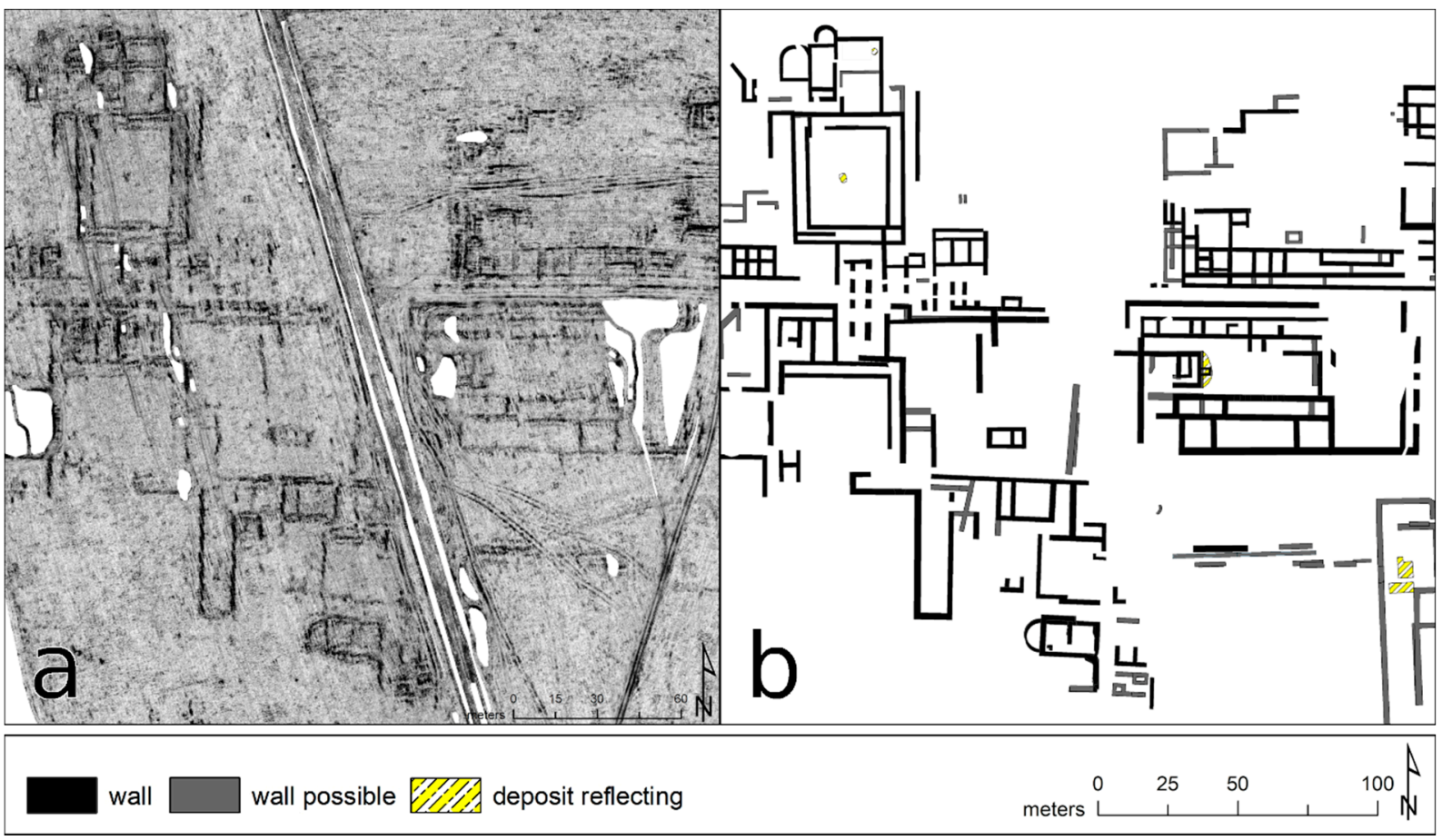

Figure 14. (a) Detail of the GPR data as depth-slice of the approximate depth range $(0.8,1.2) \mathrm{m}$. (b) Corresponding archaeological interpretation of all GPR depth-slice images. The label "deposit reflecting" marks observed reflective structures that could not be assigned unambiguously yet but were deemed relevant to the general interpretation.

\subsection{Magnetometry}

In areas where all three prospection methods could be applied, magnetometry yielded the most archaeologically relevant structures. Throughout, the wall remains show as negative magnetic anomalies, which suggests the presence of buried limestone walls rather than brick walls (Figure 15a). In contrast to the negatively magnetized walls, many assumed internal rooms show a slightly higher positive magnetization than the surrounding soil. Partly, this observation coincides with reflective layers visible in the GPR data, which are interpreted as floors, possibly consisting of burned bricks. However, the positive 
magnetization could also be caused by infill material of higher magnetization, such as roof tiles.

Throughout the town, particularly in the immediate vicinity of the indicated walls, strong accumulations of countless magnetic dipoles can be observed. These could possibly be caused by the debris of thermoremanent magnetized material, such as collapsed brick walls or roof tiles. In some cases, these accumulations still hint at right-angled structures, which is why it must be assumed that the thermoremanent magnetized rubble possibly overlays buried architectural wall remains.

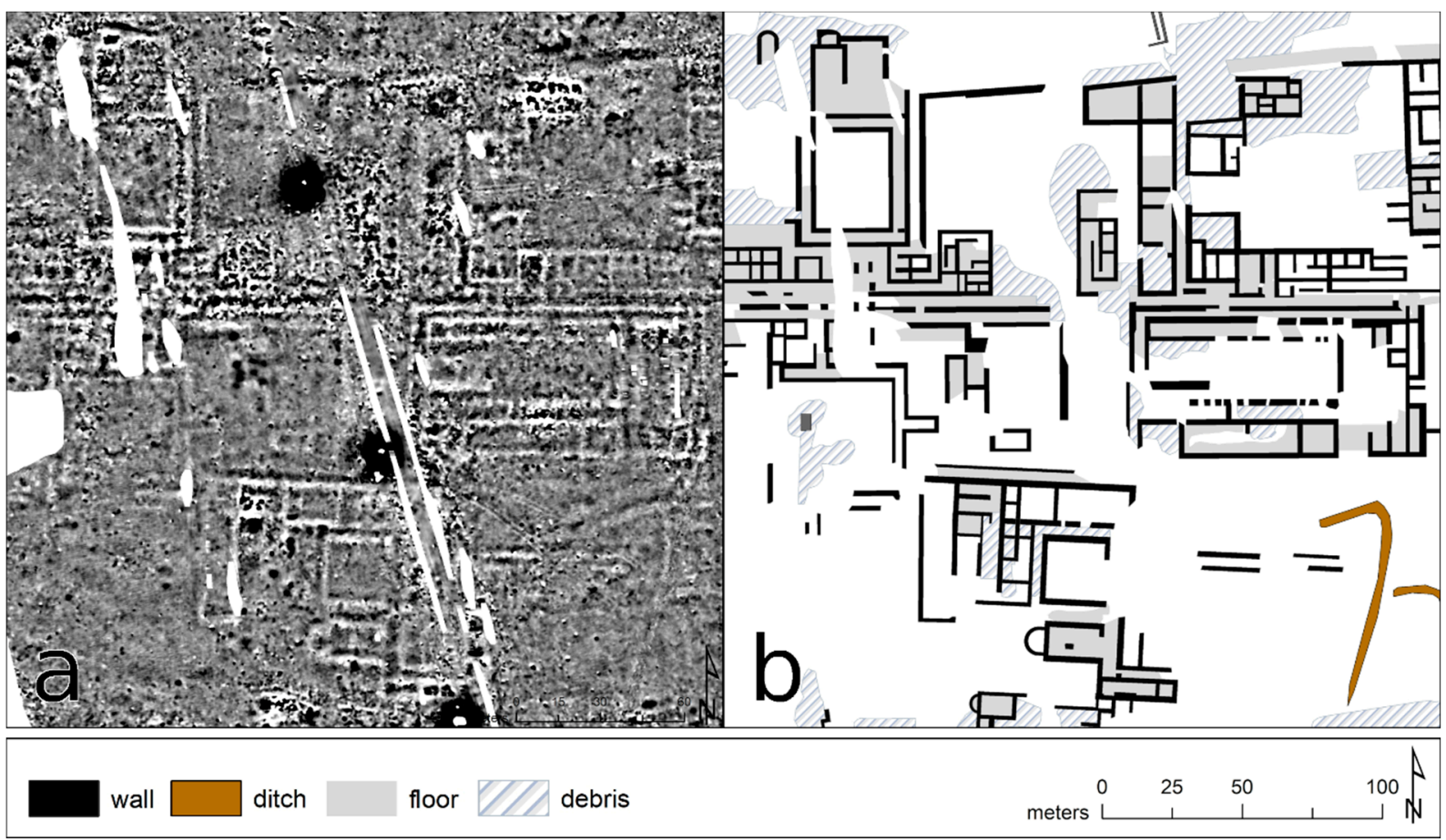

Figure 15. (a) Detail of the greyscale magnetic data image with clip-off values at $-6 \mathrm{nT}$ (white) and $+6 \mathrm{nT}$ (black). (b) Corresponding archaeological interpretation of the magnetic prospection data.

Similar urban structures with negative magnetic walls and possible thermoremanent magnetized rubble, both of Roman and other origin, have been observed in magnetic prospection data collected at various other archaeological sites $[24,26,31,55]$. In some of those cases, the interpretation of the prospection data has been well supported by a long research history and numerous excavations, showing substantial material remains which caused the observed negative magnetic anomalies [55,56]. In the case of Bassianae, although less intensively excavated, there is some comparative evidence available as well, among others in the form of mosaic floors, brick aqueducts, and hypocausts [2,6]. Buried remains of hypocausts also could explain the presence of strong dipole anomalies caused by thermoremanent magnetized elements [57]. The excavation trenches from 1935 are still clearly visible in the terrain today (Figure 16). A comparison between the excavation results and the magnetic data shows a high level of agreement, whereby the area of the hypocaust excavated in the east appears as positive anomaly (Figure 16 yellow box), as does the structure in the north-eastern corner. However, whether these anomalies are due to possible in situ remaining archaeology is difficult to decide, as the second excavated hypocaust is not visible in the magnetic data. Josip Brunšmid and Wilhelm Kubitschek also reported that the plain was still littered with bricks when they visited the site in 1879, while the large limestone blocks had been quarried so that no trace of any wall was left [58]. The question of what caused the majority of negative magnetic linear anomalies at Bassianae, interpreted as walls, thus remains open. 
The greatest added value of the magnetic prospection data, however, lies in the detection of numerous smaller buildings in the north-western and south-western parts of the town (Figure 11a). Some of which are as well indicated as shallow depressions in the DSM, but beyond that, the magnetic dataset is the only one providing more information on these zones and structures, significantly broadening our understanding of the town structure of Bassianae.

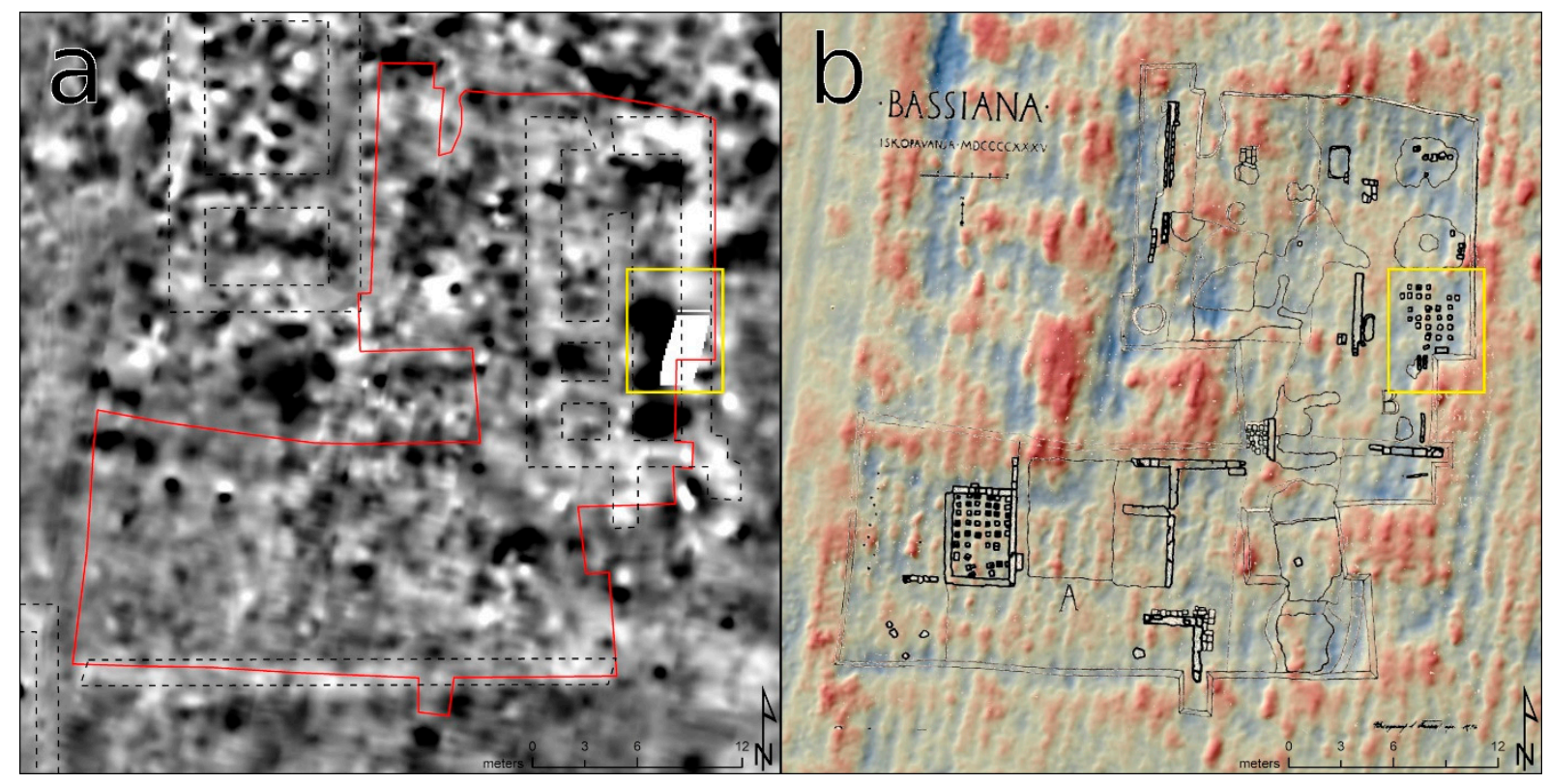

Figure 16. Comparison between the magnetic data (a) and the excavation results from 1935 (b) superimposed on a simple local relief model fused with a hillshade. The excavated area is visible in the topography and partly can be recognized in the magnetic data (red line). While the excavation has left an imprint on the magnetic data, there still exists some agreement between excavated structures and magnetic anomalies (e.g., yellow box). The magnetic data interpretation shown in (a) as dotted lines was done prior to and independently of the comparison with the excavation results. Drawing: [6] (p. 2).

\section{Discussion}

After combining all survey results (Figure 17), it can be concluded that Bassianae was built on an elevated landform in the center of an alluvial fan. The intramural town covers about 23.2 ha and rises on average $4 \mathrm{~m}$ above the surrounding terrain. The integrated interpretation of all prospection data resulted in an idealized interpretative map that not only considers all results and structures observed in the different survey data, but also tries to fill some of the many remaining voids (Figure 18). In this process, all available additional information was used.

While Figure 17 is a mere presentation of all structures observed in the different survey datasets, with some interpretative preselection and division regarding their possible archaeological origin applied, Figure 18 shows a normalized interpretation of how the town layout may have looked like. However, the latter map might still contain archaeological structures from several asynchronous occupation phases and with different levels of certainty. Black polygons mark walls interpreted with relative high certainty, light grey polygons indicate roads, black and grey hatched polygons primarily mark towers and other buildings whose existence is rather certain, but whose dimensions could not be clearly determined. Dark grey walls and buildings are, however, typically less supported by the survey data and more based on the surrounding data, thereby considering general orientations, more subtle topographic features, the expected logical continuation of features, and the suspected position of certain buildings. A similar approach was used trying to complete the road network with dotted lines. Here, there were usually some indications in various data sets, however, those were deemed too vague to draw them more prominently. 


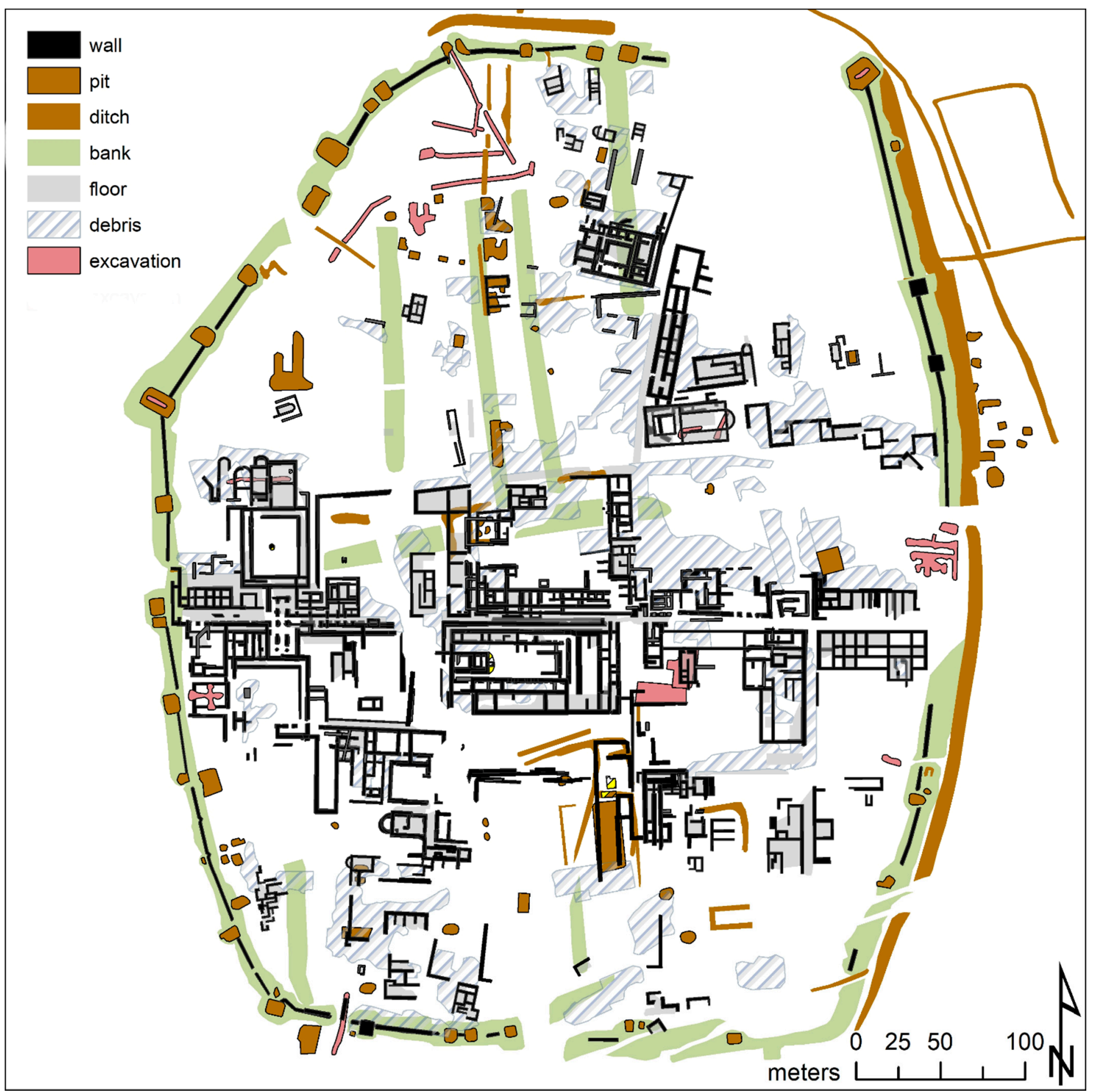

Figure 17. Interpretative map showing the result of the integrated archaeological interpretation of all three datasets.

\subsection{Fortification}

Bassianae was enclosed by a $1.8 \mathrm{~km}$ long wall (Figure 18). It appears, as if an elliptical shape with flattened sides in the north and south was intended for the town's general layout, which was only prevented from a more symmetrical shape in the northwest by the course of the creek, where the wall runs straight in a south-southwest to north-northeast direction. The wall could only be surveyed with GPR over a length of about $65 \mathrm{~m}$ in the southwest of the town. Derived from these data one can assume an average width of $1.8 \mathrm{~m}$ for the wall. Most of the towers built along the wall, which can still be located with some certainty, are separated by 45 to $50 \mathrm{~m}$. Since these regular intervals can be traced over a long distance of the fortification, they were also used for determining the likely positions 
of numerous towers in the east of the town, where they could be well integrated into the recognizable structures.

The towers were more difficult to interpret, since their square or rectangular excavation pits, visible in the DSM, and in three cases as faint square anomalies in the magnetic data (Figure 17), did not make their exact size and extent discernible. However, it seems that a general distinction can be made between two types of towers: smaller towers along the walls, with an approximate size between $6 \mathrm{~m} \times 6 \mathrm{~m}$ and $8 \mathrm{~m} \times 8 \mathrm{~m}$, and larger towers at corners or other critical points with a probable average size between $10 \times 10 \mathrm{~m}$ and $12 \times 12 \mathrm{~m}$. Most towers seem to have in common that they protrude outwards from the town wall.

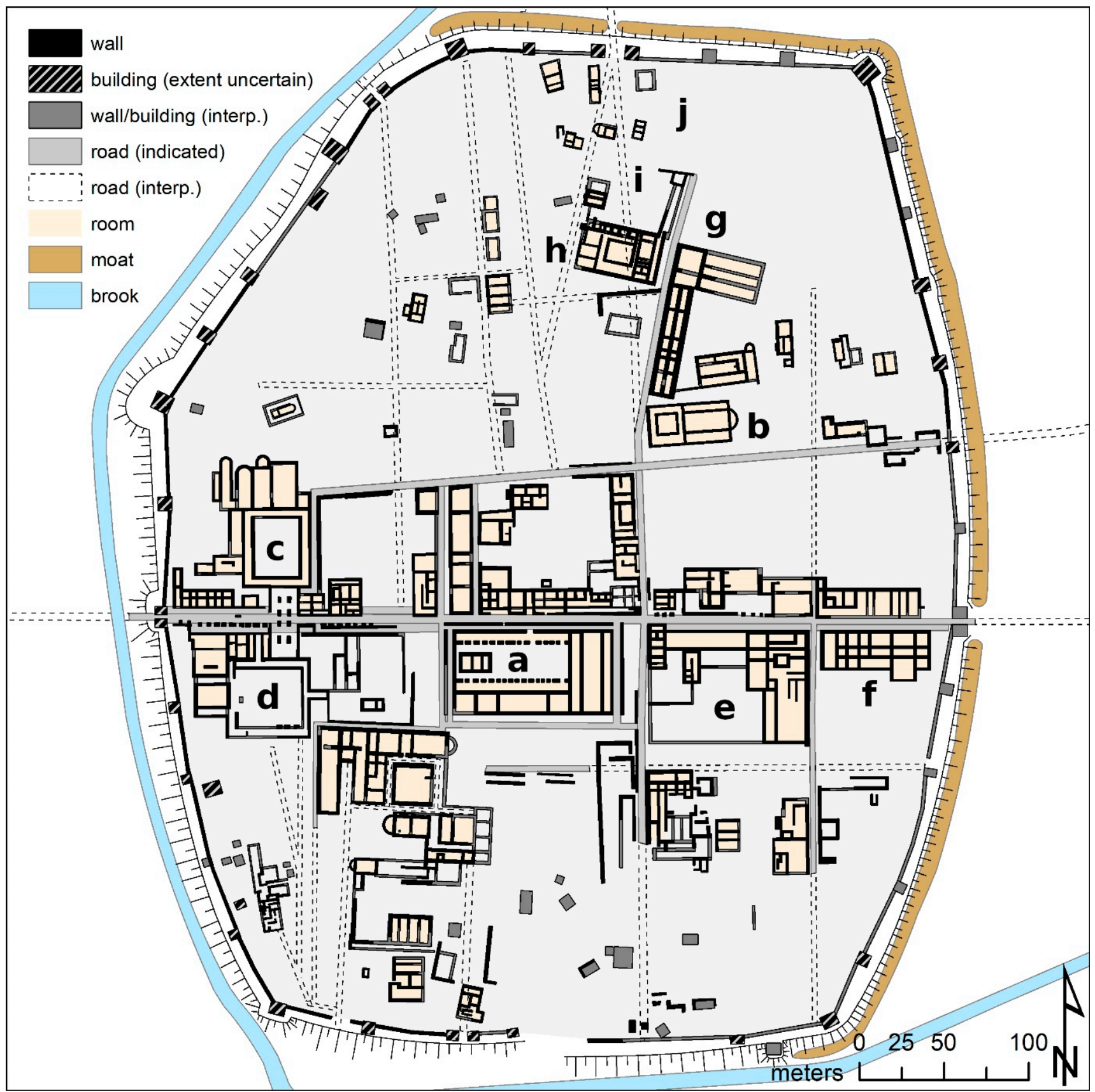

Figure 18. Idealized interpretative map of the town with the forum (a), the basilica excavated by Grbić in 1935 (b), two large courtyards (c,d), an insula also partly excavated in 1935 (e), suspected tabernae at the east gate (f), possible early christian buildings $(\mathbf{g}, \mathbf{h})$ that superimpose an older road (i), as well as several smaller individual buildings in the north (j). 
In the plan from 1935 it is suggested that the eastern part of the town wall was constructed almost in north-south direction (Figure 19a), which can neither be comprehended by the 2014 survey data nor based on the reproduction of the aerial image from 1935 (Figure 3a). If this interpretation was not due to observations made on the ground in 1935 that have since vanished, this deviation of the wall's general course might have been drawn due to the misinterpretation of other internal structures as possible towers. The latter derivation would also explain why the wall was not drawn along the edge of the plateau by Staudinger here [8], like elsewhere, as well as the offset of the walls' courses between north and south of the eastern gate. Thus, a regular convex course of the wall over the entire length of the eastern front of the town and following the topography seems more likely.

The exact number and position of the gates are still tainted by uncertainty. The existence of both western and eastern gate can be assumed with great confidence due to the well-documented decumanus maximus. However, as with the eastern front of the fortification, the east gate could not be discerned exactly; its hypothetical position and extent was thus merely interpreted. Apart from those two gates, several other possible gates in the north and south are indicated in the data yet could not be identified with certainty due to the equally vague information on the road network in these areas.

\subsection{Road Network and Insulae}

The east-west running decumanus maximus is the main axis of Bassianae (Figure 18) as part of the Singidunum-Sirmium route. It directly connects the west gate with the east gate with ca. $460 \mathrm{~m}$ distance in between. The survey data suggests that this main road has (at least in the west) an average width of ca. $13 \mathrm{~m}$, which can be divided into three parallel elements. The central area of ca. $5 \mathrm{~m}$ width represents a continuous trackway. The two areas to the north and south, each approximately $3.5 \mathrm{~m}$ to $4 \mathrm{~m}$ wide, are interpreted as porticoes or sidewalks. Since it is rather difficult to derive exact distances and demarcations from the magnetic and topographic data here, a certain degree of uncertainty must be considered. Due to the clearly visible quarrying activities along the main street, the exact construction of the porticos can only be described vaguely. The street front seems to be defined by individual column foundations placed at a distance of approximately 4 to $5 \mathrm{~m}$ from each other. Only in the area of the forum this may have been changed to form a continuous wall.

In the magnetic data, the central road is characterized by a significantly increased magnetization, which could be due to the accumulation of ferromagnetic minerals, underlying rubble of thermoremanent magnetized material, or canalization involving brick constructions. Along the entire northern side of the main road and on the southern side in the east, many building complexes show a rather narrow and uniform room layout. This building layout with the first row of rooms facing the main road, would suggest shops (tabernae).

There exists no general right-angled construction grid. One can observe some rightangled building blocks (insulae) south of the decumanus maximus. North of it, a second major street can be seen, whose orientation shows a distinct angle towards the orientation of the decumanus maximus. Oddly skewed building alignments appear in the peripheral areas, especially in the northeastern part of the town.

It seems that the buildings in the central area were constructed with stone walls, probably large sandstone or limestone blocks. These massive walls were later quarried, leaving deep trenches in the topography which can be clearly visualized in the DSM. Many of the larger structures probably represent public buildings or outstanding private residential complexes.

According to the available data, the area within the town walls appears to be unevenly built-up. In contrast to the densely built zones along the main street, the peripheral areas in the north and south of the town show wide gaps between buildings (Figure 18). The magnetic data shows a few buildings in these areas that evidently have not been excavated yet. One 
can assume that the topography shows the location of the majority of those buildings within the town walls that have been constructed as massive stone architecture. In the center of the town the forum-insula can be located (Figure 18a), with a central courtyard and possible forum temple in the west, as well as a probable forum basilica to the east.

Clearly distinguishable from the other insulae are two large building complexes near the west gate, each grouped around a large courtyard. The complex north of the main street comprises a portico and several apse halls (Figure 18c). Access to this building from the street was apparently through a large entrance hall, which continued in a similar form on the south side of the street, where it led into a second large courtyard (Figure 18d). On the west side of this second courtyard, a rectangular building is indicated in the topography in a very prominent position. Another temple could be interpreted here, as already suspected by Šime Ljubić [5].

Based on the geophysical survey data and the DSM, the building structures southeast of this second courtyard and of the forum can only be reconstructed fragmentarily. The interpretative plan from 1935 (Figure 19a) already suggests the existence of further courtyards enclosed by long corridors as well as large rooms, some with apses. It is also noticeable that most of the structures in this area are no longer strictly east-west oriented. The new investigations confirm this impression and add further details. Towards the south, the development continues with the same divergent orientation of the buildings. Near the town wall, however, very small structures with yet another deviating spatial alignment can be seen.

In the southeast quadrant of the town, at least four more insulae can be expected, including one rectangular block of buildings (Figure 18e), directly to the east of the forum. More detailed statements on the exact extent and internal structure of these insulae are currently not possible. In contrast to the plan from 1935 (Figure 19a), however, the general orientation of the building alignments in the southeast seems to have been at right angles to the orientation of the forum and its surroundings. Buildings with a slightly different orientation could be attributed to later phases. Probably the greatest information gain from the 2014 surveys in this area can be seen in a large compound building block (Figure 18f), south of the main street at the eastern gate and visible in the magnetic data. It shows many similarities to the structures north of the main street, as discussed above, and thus suggests further likely tabernae. On the opposite side to the north, behind the front of the decumanus maximus, the data are less clear, nevertheless it is possible to interpret two further insulae.

In the northeast of the town, besides a disturbance caused by a 1.4 ha large modern cemetery, there are several buildings that do not respect the regular insula layout. This may be because the majority of the buildings in this area belong to a later phase, which certainly is true for two buildings that can be identified as early Christian churches (basilicae). The larger of the two (Figure 18b) was partly excavated by Miodrag Grbić in 1935 (Figure 3a1).

To the northwest of the two basilicae another prominent building can be seen (Figure 18g), consisting of an elongated tract, about $67 \times 15 \mathrm{~m}$ in size and divided into five or six pairs of elongated rooms, terminated to the north by a rectangular complex, about $24 \mathrm{~m}$ wide and at least $27 \mathrm{~m}$ long. Probably the length was up to $50 \mathrm{~m}$, but this is impossible to ascertain as the eastern part was destroyed by the cemetery.

Regarding another large building complex located to the west (Figure 18h), with the same orientation and probably divided by a road, there are major discrepancies between the 1935 plan and the new interpretation map (Figure 19). Apparently, only the southern part of this nearly $50 \mathrm{~m}$ wide and at least $30 \mathrm{~m}$ deep building is visible. These buildings, together with the two churches possibly formed an early Christian ensemble. This is also supported by the superposition of the latter compound building (Figure 18h) to a shallow ridge (Figure 17), leading to the suspected north gate, and thus interpreted as possible older road (Figure 18i).

Further to the northwest, several smaller individual buildings (Figure 18j) with sizes between $5 \times 10 \mathrm{~m}$ and $12 \times 17 \mathrm{~m}$ and different orientations can be seen in the magnetic prospection data. Most likely, these buildings were not quarried for stones deliberately 
but probably had not been constructed as massively. Neither regarding their use nor their temporal classification has it been possible to make a definite statement so far. The same applies to the few building remains that still can be made out in the north-west of the town, and which must have been heavily disturbed. Many of those structures are oriented along the parallel, north-south running ridges (Figure 17), and thus probably the original street system (Figure 18). However, this interpretation is as uncertain as the assumption that these possible streets further to the west could have been in use over the entire settlement phase of Bassianae, as no superpositions or re-orientations have been identified here.

\subsection{Outer Area}

Before the archaeological prospection presented here, there had been no systematic study of the extramural areas. The 2014 survey campaign managed to investigate 5.5 ha with magnetometry and 3.2 ha with GPR on the pasture to the northeast of the town wall. With the UAS, the entire area of 47.5 ha could be photographed. In the magnetic data and the resulting DSM, there are several large pits visible, while the magnetic data possibly show remains of a rectangular building. In a Roman town, one would also expect significant architectural remains outside the town walls. These include, above all, the cemeteries, which usually extended along the arterial roads. It can be assumed that the most prominent sepulchral monuments and burial districts of the 1st-3rd centuries AD are to be located along the east-west axis of the main road outside the town walls. The northern road leading to the Danube seems to have been of minor importance.

The areas immediately to the west and south of the town are heavily built over by modern roads and buildings, so that no comparable evidence for extramural buildings and roads could be found here. During this investigation no clearly recognizable indications of the westbound road towards Sirmium, as well as the eastbound road towards Singidunum, could be identified in the data. However, in a recent project on the usefulness of Sentinel-2 images for the identification of Roman roads, Zanni and De Rosa [59] were able to map the entire extent of this very route section, which seems to agree rather well with the general assumption made here based on the accompanying structures, that the road to the east left the town heading roughly north-northeast.

\subsection{Round-Up}

When considering the urban fabric in its totality, the here presented archaeological prospection results confirm much of the older investigations and add important new information (Figure 19). Despite the lack of building remains in the excavations by Ljubić, it is clear that the oval town fortification must have been built out of solid materials. Yet, all stone and brick have been quarried down to the bottom of the walls' foundations after Bassianae was abandoned. Besides Bassianae, the municipium Scarbantia/Sopron (Hungary) is the only known Roman town in Pannonia that featured a similar, mighty oval town fortification [60]. However, the Scarbantia towers' shape is circular or semicircular, whereas those of Bassianae are rectangular or square.

The central areas of the town of Bassianae stand out remarkably well: especially the central forum should be counted among the most important new discoveries on ancient urbanism in Pannonia. Although its small size and three-part ground plan are not unusual in the Roman world [61-63], and also the Roman town of Altinum near Venice shows some resemblances in its layout and forum [64], in Pannonia only the ground plan of the Carnuntum forum has been completely recorded so far [15,32,33], and like Bassianae, that forum was also investigated with modern archaeological prospection methods. Other town centers, such as in Aquincum/Budapest [65] or Scarbantia/Sopron [66], could only be uncovered in parts by excavations. Detailed interpretation of all existing and new data highlighted that the main urban Roman structure of Bassianae was preserved until late antiquity. Only in the peripheral areas of the walled town, there have been more significant changes, which are expressed in deviating building alignments. This includes, especially in the north-eastern part of the town, an early Christian ensemble consisting of at least one 
three-naved church with adjacent buildings. Bassianae manifests, therefore, a development that was absent in this form in northern Pannonia due to the political changes. The textile factory in Bassianae mentioned in the Notitia dignitatum has not been located so far. This is primarily because we have no detailed information on the layout of these large-scale workshops (fabricae) in late antiquity.

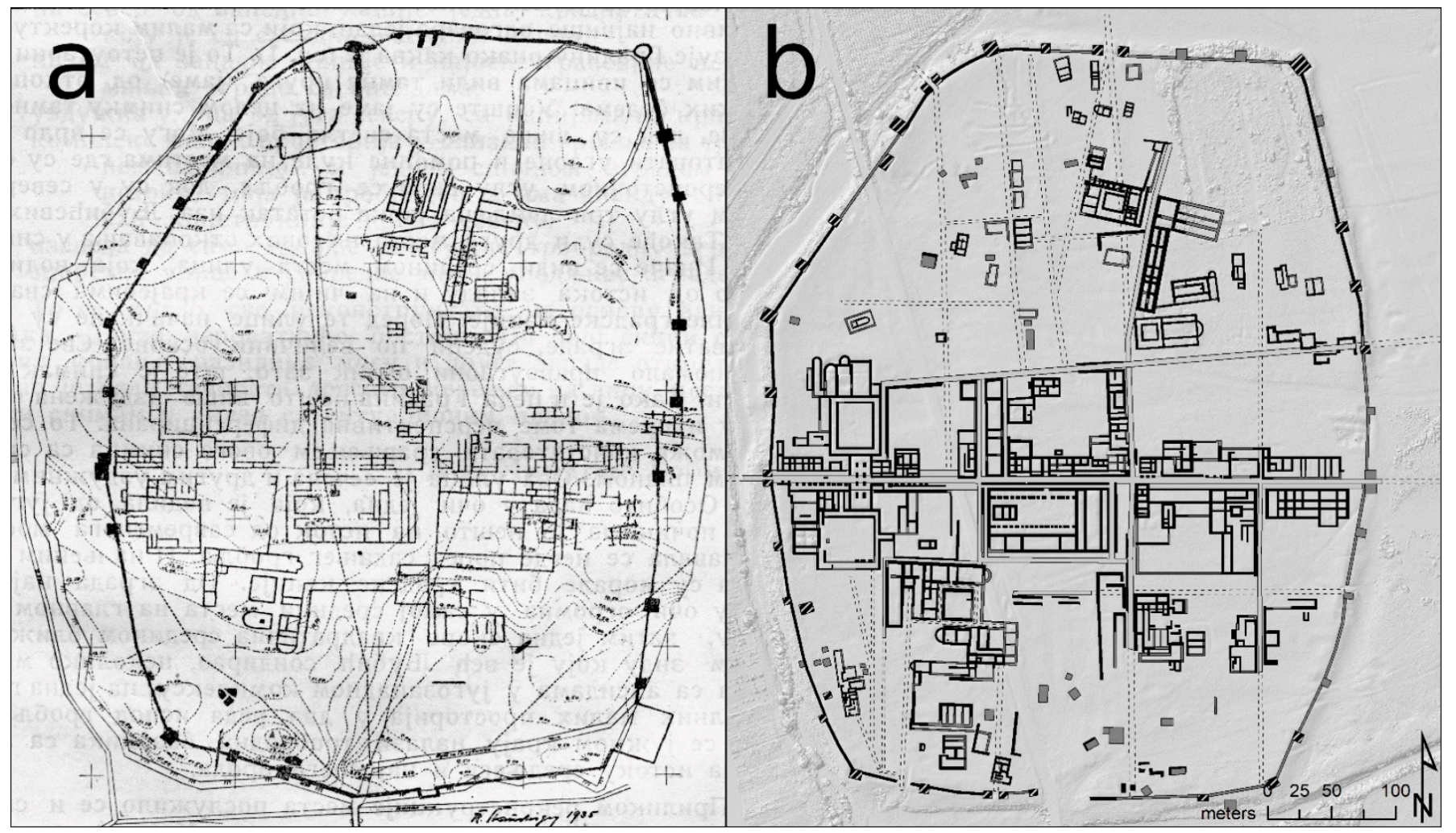

Figure 19. Comparison between the interpretative plan from 1935 (a) and the newly generated interpretation map (b). Plan: georeferenced version of the illustration in [8] (p. 29).

\section{Conclusions}

At Bassianae in present-day Serbia, a state-of-the-art approach to archaeological prospection involving optical remote sensing as well as high-resolution near-surface geophysical methods (magnetometry and GPR) was applied to noninvasively map buried (or removed) archaeological remains with the goal to further the archaeological status quo which was based on excavation results and aerial photographs from the late 19th and early 20th century. While the UAS-based aerial photographs led to the creation of a very insightful digital surface model, the geophysical surveys were seriously hampered by the in parts very uneven topography with deep trenches. Lack of radar antenna ground coupling and an apparently high electrical conductivity of the soil limited the signal penetration depth of the GPR pulse in many parts of the site. Likewise, the magnetometry survey was affected by these rough surface conditions. In some cases, it is difficult to differentiate the extent to which the observed GPR and magnetic anomalies are caused by surface undulations or archaeological remains buried in the subsurface. Nevertheless, given the unique archaeological nature of this site and despite the challenging survey conditions, an updated and more complete map of the small, late antique town of Bassianae could be derived from the 2014 prospection data, thereby illustrating the benefit of an archaeological prospection approach integrating complementary survey methods.

Author Contributions: Conceptualization, R.F., V.I., G.J.V., C.G., I.B. and M.W.; methodology, R.F., G.J.V., C.G., K.L., H.S., M.W., I.T. and W.N.; software, A.H.; formal analysis, R.F., G.J.V., K.L., H.S., 
M.W., I.T., T.T. and A.H.; investigation, R.F., G.J.V., K.L., H.S. and N.M.; resources, V.I., K.L., F.D., R.D. and W.N.; data curation, R.F., G.J.V., C.G., K.L., M.W., T.T. and A.H.; writing-original draft preparation, R.F., V.I., G.J.V., C.G., I.B., M.W. and I.T.; writing-review and editing, R.F., V.I., G.J.V., C.G., K.L., I.B., H.S., M.W., I.T., T.T., A.H., N.M., R.D., F.D. and W.N.; visualization, R.F., V.I., G.J.V. and I.B.; funding acquisition, V.I., F.D. and W.N. All authors have read and agreed to the published version of the manuscript.

Funding: This research received no external funding.

Acknowledgments: The surveys were conducted by the Ludwig Boltzmann Institute for Archaeological Prospection and Virtual Archaeology (LBI ArchPro) in collaboration with the Institute of Archaeology in Belgrade, the Römisch-Germanisches Zentralmuseum Archaeological Research Institute (RGZM) in Mainz as well as the Austrian Academy of Sciences (OeAW-IKAnt) in Vienna. The Ludwig Boltzmann Institute for Archaeological Prospection and Virtual Archaeology (archpro.lbg.ac.at, accessed on 31 March 2021) is based on an international cooperation of the Ludwig Boltzmann Gesellschaft (A), Amt der Niederösterreichischen Landesregierung (A), University of Vienna (A), TU Wien (A), ZAMG-Central Institute for Meteorology and Geodynamics (A), Airborne Technologies (A), 7reasons (A), LWL-Federal state archaeology of Westphalia-Lippe (D), NIKU—Norwegian Institute for Cultural Heritage (N), Vestfold fylkeskommune-Kulturarv (N) and ArcTron 3D (D). We gratefully acknowledge the Dioraphte Foundation (the Netherlands) for having funded the quadcopter. We also would like to thank Erich Draganits (Department of Geology, University of Vienna) for his geological advice as well as the anonymous reviewers for their comments and suggestions.

Conflicts of Interest: The authors declare no conflict of interest.

\section{References}

1. Beutler, F. Ein neuer Decurio von Bassianae. In "Eine ganz normale Inschrift" ... und ähnliches zum Geburtstag von Ekkehard Weber-Festschrift zum 30. April 2005; Beutler, F., Hameter, W., Eds.; Österreichische Gesellschaft für Archäologie: Wien, Austria, 2005; pp. 215-216.

2. Milin, M. Bassianae. In The Autonomous Towns of Noricum and Pannonia. Pannonia II; Šašel Kos, M., Scherrer, P., Eds.; Narodni muzej Slovenije: Ljubljana, Slovenia, 2004; pp. 253-268, ISBN 961-6169-30-0.

3. Dušanić, S. Bassianae and Its Territory. Archaeol. Iugosl. 1967, 8, 67-81.

4. Notitia Dignitatum, Accedunt Notitia Urbis Constantinopolitanae et Latercula Provinciarum; Seeck, O., Ed.; Minerva: Frankfurt am Main, Germany, 1962.

5. Ljubić, Š. Arkeologička izkapanja na Petrovačkoj gradini u Sriemu, gdje tobož starorimska Bassianis. Viestn. Hrvat. Arkeol. Družtva 1883, 5, 33-49.

6. Grbić, M. Arhitektura u Basijani (Sremski Petrovci) II. Glas. Istor. Društva Novom Sadu 1937, 10, 1-7.

7. Grbić, M. Bassianae, Yugoslavia (Plate VI). Antiquity 1936, 10, 475-477. [CrossRef]

8. Grbić, M. Arhitektura u Basijani (Sremski Petrovci) I. Glas. Istor. Društva Novom Sadu 1936, 9, $19-31$.

9. Crawford, O.G.S. Air Survey and Archaeology. Geogr. J. 1923, 61, 342-360. [CrossRef]

10. Reeves, D.M. Aerial Photography and Archaeology. Am. Antiq. 1936, 2, 102-107. [CrossRef]

11. Bugarski, I.; Ivanišević, V. Primena aerofotografije u srpskoj arheologiji. Saopštenja 2014, 46, 251-263.

12. Crawford, O.G.S. Letter of O.G.S. Crawford to Miodrag Grbić; Archive of the Serbian Academy of Sciences and Arts: Sremski Karlovci, Serbia, 13 October 1936.

13. Bandović, A.D. Miodrag Grbić I Nastanak Kulturno-Istorijske Arheologije U Srbiji. Ph.D. Thesis, University of Belgrade, Belgrade, Serbia, 2019.

14. Keay, S.; Millett, M.; Poppy, S.; Robinson, J.; Taylor, J.; Terrenato, N. Falerii Novi: A new survey of the walled area. Pap. Br. Sch. Rome 2000, 68, 1-93. [CrossRef]

15. Eder-Hinterleitner, A.; Ertel, C.; Ferschin, P.; Kandler, M.; Löcker, K.; Melichar, P.; Neubauer, W.; Seren, S. Das Forum des municipium Aelium Karnuntum. In Legionsadler Und Druidenstab: Vom Legionslager Zur Donaumetropole; Katalogband; Sonderausstellung Aus Anlass Des Jubiläums "2000 Jahre Carnuntum", Archäologisches Museum Carnuntinum Bad Deutsch-Altenburg 21 März $2006-11$ November 2007; Humer, F., Ed.; Amt der NÖ Landesregierung: St. Pölten, Austria, 2006; pp. 280-295, ISBN 9783854602293.

16. Keay, S.; Earl, G.P.; Hay, S.; Kay, S.; Ogden, J.; Strutt, K.D. The role of integrated geophysical survey methods in the assessment of archaeological landscapes: The case of Portus. Archaeol. Prospect. 2009, 16, 154-166. [CrossRef]

17. Seren, S.; Hinterleitner, A.; Gschwind, M.; Neubauer, W.; Löcker, K. Combining data of different GPR systems of surveys of the roman fort Qreiye-cAyyash, Syria. Archeosciences 2009, 33, 353-355. [CrossRef]

18. Saey, T.; Van Meirvenne, M.; de Smedt, P.; Neubauer, W.; Trinks, I.; Verhoeven, G.J.J.; Seren, S. Integrating multi-receiver electromagnetic induction measurements into the interpretation of the soil landscape around the school of gladiators at Carnuntum. Eur. J. Soil Sci. 2013, 64, 716-727. [CrossRef] 
19. Gugl, C.; Neubauer, W.; Nau, E.; Jernej, R. Das Militärlager in Virunum (Noricum): Zur Stationierung von römischen Truppen (singulares) an Statthaltersitzen-Teil 2. CarnuntumJB 2016, 2014, 55-66. [CrossRef]

20. Keay, S.J.; Parcak, S.H.; Strutt, K.D. High resolution space and ground-based remote sensing and implications for landscape archaeology: The case from Portus, Italy. JAS 2014, 52, 277-292. [CrossRef]

21. Neubauer, W.; Gugl, C.; Scholz, M.; Verhoeven, G.J.J.; Trinks, I.; Löcker, K.; Doneus, M.; Saey, T.; Van Meirvenne, M. The discovery of the school of gladiators at Carnuntum, Austria. Antiquity 2014, 88, 173-190. [CrossRef]

22. Gugl, C.; Neubauer, W.; Nau, E.; Jernej, R. New evidence for a Roman military camp at Virunum (Noricum). Archaeol. Pol. 2015, 53, 289-292.

23. Gugl, C.; Neubauer, W.; Wallner, M.; Löcker, K.; Verhoeven, G.J.J.; Humer, F. Die Canabae von Carnuntum. Erste Ergebnisse der geophysikalischen Messungen 2012-2015. In Legionslager und Canabae Legionis in Pannonien: Internationale Archäologische Konferenz. Budapest, 16-17 November 2015; Beszédes, J., Ed.; Historisches Museum der Stadt Budapest: Budapest, Hungary, 2016; pp. 29-43, ISBN 978-615-5341-31-1.

24. Lambers, L.; Fassbinder, J.; Ritter, S.; Ben Tahar, S. Meninx-Geophysical prospection of a Roman town in Jerba, Tunisia. In AP2017: 12th International Conference of Archaeological Prospection, University of Bradford, Bradford, UK, 12-16 September 2017; Jennings, B., Gaffney, C.F., Sparrow, T., Gaffney, S., Eds.; Archaeopress Publishing: Oxford, UK, 2017; pp. 135-137, ISBN 9781784916787.

25. Neubauer, W.; Wallner, M.; Gugl, C.; Löcker, K.; Vonkilch, A.; Trausmuth, T.; Nau, E.; Jansa, V.; Wilding, J.; Hinterleitner, A.; et al. Zerstörungsfreie archäologische Prospektion des römischen Carnuntum—erste Ergebnisse des Forschungsprojekts "ArchPro Carnuntum". In Carnuntum Jahrbuch 2017; Pülz, A., Ed.; Verlag der Österreichischen Akademie der Wissenschaften: Wien, Austria, 2018; pp. 55-75, ISBN 978-3-7001-8372-3.

26. Ritter, S.; Ben Tahar, S.; Fassbinder, J.W.E.; Lambers, L. Landscape archaeology and urbanism at Meninx: Results of geophysical prospection on Jerba (2015). J. Rom. Archaeol. 2018, 31, 357-372. [CrossRef]

27. Pasquinucci, M.; Ducci, S.; Menchelli, S.; Ribolini, A.; Bianchi, A.; Bini, M.; Sartini, S. Ground Penetrating Radar Survey of Urban Sites in North Coastal Etruria: Pisae, Portus Pisanus, Vada Volaterrana. In Urban Landscape Survey in Italy and the Mediterranean; Vermeulen, F., Burgers, G.-J., Keay, S.J., Corsi, C., Eds.; Oxbow Books: Oxford, UK, 2012; pp. 149-159, ISBN 978-1-84217-486-9.

28. The Isola Sacra Survey: Ostia, Portus and the Port System of Imperial Rome; Keay, S.; Millett, M.; Strutt, K.; Germoni, P., Eds.; McDonald Institute for Archaeological Research, University of Cambridge: Cambridge, UK, 2020; ISBN 978-1-902937-94-6.

29. Pisz, M.; Tomas, A.; Hegyi, A. Non-destructive research in the surroundings of the Roman Fort Tibiscum (today Romania). Archaeol. Prospect. 2020, 27, 219-238. [CrossRef]

30. Verdonck, L.; Launaro, A.; Vermeulen, F.; Millett, M. Ground-penetrating radar survey at Falerii Novi: A new approach to the study of Roman cities. Antiquity 2020, 94, 705-723. [CrossRef]

31. Martorella, F. Magnetic Survey at the Roman Military Camp of el Benian in Mauretania Tingitana (Morocco): Results and Implications. Remote Sens. 2021, 13, 28. [CrossRef]

32. Kandler, M. Das Forum der Colonia Carnuntum: Erste Ergebnisse von geophysikalischen Bodenprospektionen im Tiergarten des Schlosses Petronell. In Steine und Wege: Festschrift für Dieter Knibbe zum 65. Geburtstag; Scherrer, P., Taeuber, H., Thür, H., Eds.; Österreichisches Archäologisches Institut: Wien, Austria, 1999; pp. 359-368, ISBN 9783900305291.

33. Neubauer, W.; Doneus, M.; Trinks, I.; Verhoeven, G.J.J.; Hinterleitner, A.; Seren, S.; Löcker, K. Long-term Integrated Archaeological Prospection at the Roman Town of Carnuntum/Austria. In Archaeological Survey and the City; Johnson, P., Millett, M., Eds.; Oxbow Books: Oxford, UK, 2012; pp. 202-221, ISBN 978-1842175095.

34. Opitz, R. Integrating lidar and geophysical surveys at Falerii Novi and Falerii Veteres (Viterbo). Pap. Br. Sch. Rome 2009, 77, 1-27. [CrossRef]

35. Sandici, V.; Scherzer, D.; Hinterleitner, A.; Trinks, I.; Neubauer, W. An unified magnetic data acquisition software for motorized geophysical prospection. In Archaeological Prospection, Proceedings of the 10th International Conference on Archaeological Prospection, Vienna, Austria, 29 May-2 June 2013; Neubauer, W., Trinks, I., Salisbury, R.B., Einwögerer, C., Eds.; Austrian Academy of Sciences Press: Vienna, Austria, 2013; pp. 378-379, ISBN 978-3-7001-7459-2.

36. Hinterleitner, A.; Neubauer, W.; Trinks, I. Removing the influence of vehicles used in motorized magnetic prospection systems. In Archaeological Prospection, Proceedings of the 10th International Conference on Archaeological Prospection, Vienna, Austria, 29 May-2 June 2013; Neubauer, W., Trinks, I., Salisbury, R.B., Einwögerer, C., Eds.; Austrian Academy of Sciences Press: Vienna, Austria, 2013; pp. 384-386, ISBN 978-3-7001-7459-2.

37. Trinks, I.; Hinterleitner, A.; Neubauer, W.; Nau, E.; Löcker, K.; Wallner, M.; Gabler, M.; Filzwieser, R.; Wilding, J.; Schiel, H.; et al. Large-area high-resolution ground-penetrating radar measurements for archaeological prospection. Archaeol. Prospect. 2018, 25, 171-195. [CrossRef]

38. Förstner, W.; Wrobel, B.P. Photogrammetric Computer Vision: Statistics, Geometry, Orientation and Reconstruction; Springer International Publishing: Cham, Switzerland, 2016; ISBN 978-3-319-11549-8.

39. Luhmann, T.; Fraser, C.S.; Maas, H.-G. Sensor modelling and camera calibration for close-range photogrammetry. ISPRS J. Photogramm. Remote Sens. 2016, 115, 37-46. [CrossRef]

40. Verhoeven, G.J.; Filzwieser, R.; Wallner, M. 3D surface modelling from multi-copter images: It is not always an obvious success. Drones 2021. in preparation. 
41. Brovelli, M.A.; Crespi, M.; Fratarcangeli, F.; Giannone, F.; Realini, E. High resolution satellite imagery orientation accuracy assessment by leave-one-out method: Accuracy index selection and accuracy uncertainty. In GeoInformation in Europe: Proceedings of the 27th Symposium of the European Association of Remote Sensing Laboratories, Bolzano, Italy, 4-7 June 2007; Gomarasca, M.A., Ed.; Millpress: Rotterdam, The Netherlands, 2008; pp. 617-624, ISBN 978-90-5966-061-8.

42. Verhoeven, G.J. Mesh Is More-Using All Geometric Dimensions for the Archaeological Analysis and Interpretative Mapping of 3D Surfaces. J. Archaeol. Method Theory 2017, 24, 999-1033. [CrossRef]

43. Agisoft LLC. Agisoft Metashape Change Log. 2021. Available online: https://www.agisoft.com/pdf/metashape_changelog.pdf (accessed on 31 March 2021).

44. Brovelli, M.A.; Crespi, M.; Fratarcangeli, F.; Giannone, F.; Realini, E. Accuracy assessment of High Resolution Satellite Imagery by Leave-one-out method. In Proceedings of the Accuracy 2006: 7th International Symposium on Spatial Accuracy Assessment in Natural Resources and Environmental Sciences, Lisbon, Portugal, 5-7 July 2006; Caetano, M., Painho, M., Eds.; Instituto Geográfico Português: Lisboa, Portugal, 2006; pp. 533-542, ISBN 978-972-8867-27-0.

45. Brovelli, M.A.; Crespi, M.; Fratarcangeli, F.; Giannone, F.; Realini, E. Accuracy assessment of high resolution satellite imagery orientation by leave-one-out method. ISPRS J. Photogramm. Remote Sens. 2008, 63, 427-440. [CrossRef]

46. Trinks, I.; Neubauer, W.; Doneus, M. Prospecting Archaeological Landscapes. In Progress in Cultural Heritage Preservation, Proceedings of the 4th International Conference, EuroMed 2012, Lemessos, Cyprus, 29 October-3 November 2012; Ioannides, M., Fritsch, D., Leissner, J., Davies, R., Remondino, F., Caffo, R., Eds.; Springer: Berlin/Heidelberg, Germany, 2012; pp. 21-29, ISBN 978-3-64234233-2.

47. Filzwieser, R.; Olesen, L.H.; Verhoeven, G.J.J.; Mauritsen, E.S.; Neubauer, W.; Trinks, I.; Nowak, M.; Nowak, R.; Schneidhofer, P.; Nau, E.; et al. Integration of Complementary Archaeological Prospection Data from a Late Iron Age Settlement at VesteragerDenmark. J. Archaeol. Method Theory 2018, 25, 313-333. [CrossRef]

48. Doneus, N.; Neubauer, W.; Doneus, M.; Wallner, M. Die archäologische Landschaft von Halbturn. Ergebnisse aus drei Jahrzehnten integrierter archäologischer Prospektion. Archaeologia 2018, 1, 201-226. [CrossRef]

49. Hesse, R. Visualisierung hochauflösender Digitaler Geländemodelle mit LiVT. In 3D-Anwendungen in der Archäologie. Computeranwendungen und Quantitative Methoden in der Archäologie. Workshop der AG CAA und des Exzellenzclusters Topoi 2013; Lieberwirth, U., Herzog, I., Eds.; Edition Topoi: Berlin, Germany, 2016; pp. 109-128, ISBN 978-3-9816751-4-6.

50. Yokoyama, R.; Shirasawa, M.; Pike, R.J. Visualizing topography by Openness: A new application of image processing to digital elevation models. Photogramm. Eng. Remote Sens. 2002, 68, 251-266.

51. Doneus, M. Openness as Visualization Technique for Interpretative Mapping of Airborne Lidar Derived Digital Terrain Models Remote Sens. 2013, 5, 6427-6442. [CrossRef]

52. Hesse, R. LiDAR-derived Local Relief Models-A new tool for archaeological prospection. Archaeol. Prospect. 2010, 17, 67-72. [CrossRef]

53. Zakšek, K.; Oštir, K.; Kokalj, Ž. Sky-View Factor as a Relief Visualization Technique. Remote Sens. 2011, 3, 398-415. [CrossRef]

54. Kokalj, Ž.; Somrak, M. Why Not a Single Image? Combining Visualizations to Facilitate Fieldwork and On-Screen Mapping. Remote Sens. 2019, 11, 747. [CrossRef]

55. Filzwieser, R.; Aladzhov, A.; Schlegel, J.; Hinterleitner, A.; Doneus, N.; Schiel, H.; Dimitrov, J.; Gamon, M.; Daim, F.; Neubauer, W. Pliska-Integrated geophysical prospection of the first Early Medieval Bulgarian capital. Bulg. e-Spis. Arkheologiya-Bulg. e-J. Archaeol. 2019, 9, 229-261.

56. Dimitrov, J. Zur historischen Topographie Pliskas einhundert Jahre nach den ersten Ausgrabungen. In Post-Roman Towns, Trade and Settlement in Europe and Byzantium: Volume 2: Byzantium, Pliska, and the Balkans; Henning, J., Ed.; De Gruyter: Berlin, Germany, 2007; pp. 253-271, ISBN 9783110218831.

57. Neubauer, W.; Eder-Hinterleitner, A.; Seren, S.; Melichar, P. Georadar in the Roman civil town Carnuntum, Austria: An approach for archaeological interpretation of GPR data. Archaeol. Prospect. 2002, 9, 135-156. [CrossRef]

58. Brunšmid, J.; Kubitschek, W. Bericht über eine Reise in die Gegend zwischen Essegg und Mitrovica. Archäol.-Epigr. Mitt. Österr.-Ung. 1880, 4, 97-124.

59. Zanni, S.; De Rosa, A. Remote Sensing Analyses on Sentinel-2 Images: Looking for Roman Roads in Srem Region (Serbia). Geosciences 2019, 9, 25. [CrossRef]

60. Gömöri, J. Scarbantia. In The Autonomous Towns of Noricum and Pannonia I; Šašel Kos, M., Scherrer, P., Eds.; Narodni muzej Slovenije: Ljubljana, Slovenia, 2003; pp. 81-92, ISBN 961-6169-29-7.

61. Le Forum en Gaule et Dans les Régions Voisines: Ouvrage Édité avec le Concours du Laboratoire TRACES (Toulouse II-Le Mirail-CNRS, UMR 5608); Bouet, A., Ed.; Ausonius Éditions: Bordeaux, France, 2012; ISBN 978-2-35613-075-4.

62. Bouet, A. Le problème du "forum" dans les agglomérations secondaires: L'exemple de Verdes (Loir-et-Cher). In Territoires et Paysages de L'âge du Fer au Moyen Âge: Mélanges Offerts à Philippe Leveau; Bouet, A., Verdin, F., Eds.; Ausonius Éditions: Bordeaux, France, 2005; pp. 63-73, ISBN 978-2910023652.

63. Schalles, H.-J. Forum Und Zentraler Tempel Im 2. Jahrhundert n. Chr. In Die Römische Stadt im 2. Jahrhundert n.Chr. Der Funktionswandel des Öffentlichen Raumes: Kolloquium in Xanten vom 2. bis 4 Mai 1990; Schalles, H.-J., von Hesberg, H., Zanker, P., Eds.; Rheinland Verlag: Köln, Germany, 1992; pp. 183-212, ISBN 9783792712528.

64. Mozzi, P.; Fontana, A.; Ferrarese, F.; Ninfo, A.; Campana, S.; Francese, R. The Roman City of Altinum, Venice Lagoon, from Remote Sensing and Geophysical Prospection. Archaeol. Prospect. 2016, 23, 27-44. [CrossRef] 
65. Groh, S.; Láng, O.; Sedlmayer, H.; Zsidi, P. Neues zur Urbanistik der Zivilstädte von Aquincum-Budapest und CarnuntumPetronell. Acta Archaeol. 2014, 65, 361-403. [CrossRef]

66. Gömöri, J. Neue Erkenntnisse Zur Topographie des Forums in Scarbantia. CarnuntumJB 1991, 1991, 57-70. 